\title{
SELECTED CASES, LEGISLATION AND DEVELOPMENTS IN OIL AND GAS LAW
}

\author{
ROWLAND J. HARRISON*
}

\begin{abstract}
The topic of Recent Cases and Developments in Oil and Gas Law was intro. duced at the Canadian Petroleum Law Foundation Ninth Annual Research Seminar in Oil and Gas Law. This article is the paper on the topic, extended to deal with recent legislation, delivered at the Tenth Annual Research Seminar. The article concentrates its comments and discussions on two areas of recent developments in oil and gas law, namely, the attitude of Canadian Courts to the interpretation of the freehold petroleum and natural gas lease and the applicability of the doctrine of estoppel to a terminated petroleum and natural gas lease.
\end{abstract}

\section{A. INTRODUCTION}

As was pointed out when this topic was introduced at the 1970 Annual Research Seminar of the Canadian Petroleum Law Foundation, a "broad brush" treatment of the various areas discussed is difficult to avoid. ${ }^{1}$ The writer has attempted to minimize the grounds for this criticism by emphasizing those cases and developments which appeared to be of greater significance. Thus, a large part of the paper discusses the Cull Case ${ }^{2}$ as this decision may well prove to be a major turning point in the attitude of Canadian Courts to the interpretation of freehold petroleum and natural gas leases. Accordingly, the discussion of the decision goes a little beyond a digest of the judgment. Similarly, the plea of estoppel in relation to oil and gas leases appears to have been finally put to rest by decisions in the past year or so and, again, some general discussion of this area is included.

In other instances, the paper is really little more than a digest of the various decisions which it was felt would be of interest to participants in this Seminar. So far as legislative developments are concerned, the discussion is restricted to a descriptive report of the reorganization of the Provincial Government as it may affect the oil and gas industry. No attempt at a legal analysis of the legislation has been made.

\section{B. TERMINATION OF LEASES}

\section{The Cull Case}

The decisions of the Appellate Division of the Supreme Court of Alberta, ${ }^{3}$ and of the Supreme Court of Canada, ${ }^{4}$ in Cull v. Canadian Superior Oil Ltd. are of major significance for two reasons. First, it appears that the "very bleak picture"5 painted by the decision in the

\footnotetext{
- Assistant Professor, Faculty of Law, Dalhousie University. I would like to express my appreciation for the assistance I received in the preparation of this paper from Professor Maurice J. Sychuk and Mr. John F. Curran. Robert W. Thompson, summer research student, assisted with the survey of legislative developments and I have also incorporated several of his comments on recent cases.

1 Currie, Recent Cases and Developments in Oil and Gas Law, (1971) 9 Alta. L. Rev. 452.

2 Cull v. Canadian Superior Oil Ltd. [1971] 3 W.W.R. 28; (1971) 20 D.L.R. (3d) 360.

3 (1970) 75 W.W.R. 606; 16 D.L.R. (3d) 709.

- Supra, n. 2.

s Supra, n. 1 at 465.
} 
Trial Division of the Supreme Court of Alberta ${ }^{6}$ has been avoided by the immediate result. Secondly, there is some encouragement in a broad interpretation of the effect of the decision, and specifically in the judgment of Johnson J.A. that the Courts may be prepared to adopt a more liberal interpretation of lease provisions relating to termination.?

On December 30, 1947, Ida Armilda Cull granted an "unless" type of petroleum and natural gas lease to the plaintiff. The relevant terms were as follows:

2. Subject to the other provisions herein contained this lease shall be for a term of ten years from this date (called 'primary term') and as long thereafter as oil, gas or other mineral is produced from the said land hereunder, or as long thereafter as Lessee shall conduct drilling, mining, or reworking operations thereon as hereinafter provided and during the production of oil, gas or other mineral resulting therefrom.

7. If prior to the discovery of oil or gas on said lands Lessee should drill a dry hole or holes thereon, or if after the discovery of oil or gas the production thereof should cease from any cause, this lease shall continue in force during the primary term, if on or before the rental paying date next ensuing after the expiration of ninety (90) days from date of completion of dry hole or cessation of production Lessee commences drilling or re-working operation or commences or resumes the payment or tender of rentals, or after the primary term if Lessee commences additional drilling or reworking operations within sixty $(60)$ days from date of completion of dry hole or cessation of production, and if production results therefrom then so long as such production continues. If, during the last year of the primary term and prior to the discovery of oil or gas on said land, Lessee should drill a dry hole thereon, anything herein contained to the contrary notwithstanding, this lease shall continue in force during the remainder of the primary term without further payment of rentals or conduct of operations upon the leased premises, and if production be obtained as herein provided, so long as such production continues.

12. If Lessee shall commence to drill a well within the term of this lease or any extension thereof, Lessee shall have the right to drill such well to completion with reasonable diligence and dispatch, and if oil or gas be found in paying quantities, this lease shall continue and be in force with like effect as if such well had been completed within the term of years herein first mentioned.

A well was spudded in on the land on November 28, 1957. Events thereafter proceeded thus:

December 28, 1957

December 29, 1957

December 30, 1957

January 2, 1958

January 5, 1958

January 6, 1958

January 7, 1958
Total Depth reached.

Production casing set. Primary term expired at midnight.

Christmas tree installed.

Rig released.

Service rig in place.

Hole circulated.

Perforating.

Further perforating.

Acid treatment.

Four to five barrels of oil returned to surface during night.

Swabs pulled.

6 (1970) 74 W.W.R. 324.

- Infra, at 397. 
Load and formation oil began to flow under pressure, discharged to sump pit.

Service rig released.

Well capable of production.

Christmas tree shut.

January 8-10, 1958 Installation of tank, separator and miscellaneous equipment.

January 11, 1958

January 13, 1958

Production of load oil.

Well on full production.

Thereafter, the well continued to produce subject to the monthly allowables set by the Oil and Gas Conservation Board.

Sinclair J. at trial, had little difficulty in holding that the lease had not terminated prior to January 7,1958-the date on which the well was first capable of production-as "the perforating, acidizing, swabbing and other operations performed on the well when the service rig was in place were involved in drilling the well to completion," within the meaning of clause 12 of the lease. ${ }^{8}$

The major difficulty he found was with the period from January 7 to January $11 .{ }^{9}$ First, His Lordship found that the words "drill such well to completion" were not broad enough to encompass the installation of the tank, separator and other equipment. He said:10

In other words, I believe the meaning of the words 'drill to completion' in clause 12 does not extend so far as to include the completion of facilities needed to treat and save the oil.

Therefore, the well had been drilled to completion by January 7 and oil had been found in paying quantities. Clause 12 provided that in this event the lease would continue in force "with like effect as if such well had been completed within the term of years herein first mentioned".

Thus, the second problem was to consider the operation of clause 2 of the lease as at January 7. Clause 2 provided for the extension of the primary term in two situations. The first was as long as "oil ... is produced", but this provision could not apply in the present situation as there had been no production between January 7 and January 11, or more probably, January 13 . Secondly, the primary term was to be extended, where oil was not produced, as long as the lessee conducted drilling, mining, or re-working operations "as hereinafter provided". Sinclair J. held these latter words to be a reference to clause 7 of the lease, which, he found, only allowed the lessee a period of 60 days after cessation of production within which to commence additional drilling or re-working operations. He said: ${ }^{11}$

In the present case there were no additional drilling or re-working operations commenced within 60 days of January 7,1958 , even if it could be said that production had ceased on that day.

Therefore, the second possible means of extending the lease under clause 2 could not apply and the lease had expired on January 7,1958 .

(1970) 74 W.W.R. 324 at 329.

9 Production was continuous, subject to the well allowable, as from January 11, 1958. However, the plaintiffs treated the first two days' production as being recovery of load oil for accounting purposes and in their records showed production as commencing on January 13, 1958. See (1970) 74 W.W.R. 324 at 330.

10 (1970) 74 W.W.R. 324 at $331-32$.

"Id. at 333. 
Although judgment was given for the plaintiff on the issue of estoppel, ${ }^{12}$ the grounds on which the lease was held to have terminated justifiably raised alarm. Logically, the decision meant that under a Kanstrup type of lease, ${ }^{13}$ wherever the primary term was extended by drilling operations resulting in a discovery, production would have to commence the very instant the well was completed. "Completion" might include perforating, acidizing, swabbing and certain other operations, but only up to the point that the well was first capable of production-any gap between this point and actual production would result in the termination of the lease. In the instant case this would have required, at the very least, that the tanks and separator be moved to the site in anticipation of the well being completed as a producer. In fact they had been ordered and installed "in a manner consistent with good oilfield practice, and with reasonable diligence and dispatch." 14 But this was not sufficient to save the lease. Clearly what was required by the decision was that a well go on production immediately it was completed, completion being determined by the moment at which the well was first capable of production. This conclusion is fortified by the finding that, even though it was physically possible to produce oil directly from the well into trucks on January 7, no prudent operator would have done so because of the danger from hydrogen sulphide. ${ }^{15}$

The logical result of the decision, on this reasoning, is that it would be impossible to ever continue the lease by the production of oil resulting from a well completed under the provisions of clause 12. Clearly, there will always be some gap between completion as defined by Sinclair $\mathrm{J}$. and actual production. His Lordship seemed to acknowledge this when he said:16

It would have been possible for Canadian Oil to have ordered and installed the tank, separator and associated equipment, and to have connected them to the well so as to produce, treat and save oil in a safe manner within a few hours after the service rig was released January 7.

But in holding that, even by proceeding diligently, the lessee had not complied with the lease, Sinclair J. left it far from clear what was required of a lessee and ignored the realities of oilfield operation.

It was in reliance on this last criticism that the decision that the lease had terminated was overruled by the Appellate Division of the Supreme Court of Alberta. ${ }^{17}$ Johnson J.A. delivering the judgment of the Court, ${ }^{18}$ gave several reasons why, in his view, the lease had not terminated. However, it is respectfully suggested that they are not entirely clear and perhaps difficult to reconcile with each other. He distinguished the earlier cases interpreting similar leases ${ }^{19}$ on the basis

12 Id. at 338 .

13 See Canadian Superior Oil of California Ltd. v. Kanstrup (1963) 39 D.L.R. (2d) 275; affirmed (1964) 43 D.L.R. (2d) 261 (Alta. App. Div.), (1965) 47 D.L.R. (2d) 1 (S.C.C.); Canadian Superior Oil Ltd. and Kerr McGee Corp'n. v. Paddon-Hughes Development Co. Ltd. and Hambly (1970) 74 W.W.R. 356, 12 D.L.R. (3d) 247; affirming (1969) 67 W.W.R. 525, 3 D.L.R. (3d) 10.

14 (1970) 74 W.W.R. 324 at 330. His Lordship continued: "There was no intention by the operator to cease operations and to continuously shut in the well. There was a bona fide intention to proceed diligently to place the well on production. That intention was carried into effect with reasonable diligence and dispatch".

is Id.

16 Id. Emphasis added. Furthermore, some of the equipment apparently had been ordered after the drill stem test on December 25. See (1970) 74 W.W.R. 324 at 329-30. Yet, it was not determined until December 24 that the well could likely be brought into production. See (1970) 75 W.W.R. 606 at 607-8; (1970) 16 D.L.R. (3d) 709 at 710-11.

17 (1970) 75 W.W.R. 606; 16 D.L.R. (3d) 709.

18 Johnson, Kane and Clement JJ.A.

19 Supra, n. 13. 
that they dealt with situations where lessees had sought to extend the lease term by payment of shut-in royalties. He said:20

\begin{abstract}
It will be seen that the present problem is quite different and, reduced to its simplest terms, is: Given a ready market for oil, does the combined effect of these clauses require that production be taken the very moment that the well has been completed? I have said "the very moment" for it must be realized that in every case there will be a period, however short, while the well is connected to the gathering systems and the valves are being turned on, when no production is obtained. It is the submission of appellant's counsel that if there is such a period of time, this Court, because of what has been said in these earlier cases, must hold that the lease has not been extended. Certainly there is nothing in the evidence to suggest that, having regard to the usual oilfield practice, it would ever be possible to have production at the exact moment the well was completed. If this argument is valid, lessees would never be able to take advantage of clause 12 .
\end{abstract}

It is submitted that this last sentence is the strength of the judgment. Clearly, if the judgment of Sinclair J. were to be upheld, the only circumstances in which clause 12 could operate would be where a shutin royalty had been paid prior to the completion of the well, to avoid the problems of the Kanstrup and Hambly cases. ${ }^{21}$ The clause could never operate with respect to an oil well, as the shut-in royalty clause in these leases refers only to gas wells. Yet, clause 12 refers to "oil or gas" being found from the drilling of a well. Such an interpretation would deprive the clause of any effect in relation to oil wells, it is suggested, contrary to the principle that the interpretation of words in a contract so as to leave them meaningless is to be avoided. Johnson J.A. clearly had this in mind when he concluded:22

It is not reasonable, I suggest, to apply so stringent an interpretation.

However, this approach causes a difficulty which was not adverted to in the judgment.

The result of the decision was that the lease continued in effect. How, in an overall perspective, was this achieved? There are three possibilities. The first is that the meaning of "to drill such well to completion" in clause 12 has been reinterpreted to include the steps taken after January 7 and until actual production on January 11 or 13. This possibility is suggested in the following passage: ${ }^{23}$

In his judgment, the learned trial Judge held that the work done between the date that the rig was removed and January 11 was part of the drilling of the well. I agree that this is the correct view.

However, it is doubtful that this was the intention for several reasons. Sinclair J. did not hold that the work up to January 11 was part of the drilling of the well. He specifically held that the well had been completed by January 7 and that "the words 'drill such well to completion' are not broad enough to encompass the steps taken by the lessee after January

20 (1970) 75 W.W.R. 606 at 610; 16 D.L.R. (3d) 709 at 713. Since presenting this paper, an experienced oil field operator in Alberta has indicated to the writer that the statement of Johnson J.A., that "in every case there will be a period ... when no production is obtained", is not strictly correct. Apparently it is possible, and in some situations it in fact happens, that the flow valve is open while the last swab is pulled so that the oil may start to flow, and production commence, before the owab has been finally removed from the well. This possibility of production being obtained without any gap after completion of the well (Sinclair J., having defined completion to include, inter alia, swabbing) would appear to negative some of the writer's subsequent comments but, as it is a possibility only, and not the usual procedure, it is doubtful that the conclusions of the Appellate Division and the Supreme Court would have differed if it had been adverted to during the proceedings.

21 Supra, n. 13.

22 (1970) 75 W.W.R. 606 at 611; 16 D.L.R. (3d) 709 at 713.

is Id. 75 W.W.R. at 609; 16 D.L.R. at 712. 
7, 1958."24 It is suggested that Johnson J.A. was referring to the work between the release of the drilling rig on December 30 and not of the service rig on January 7 in which case his reference to January 11 in the above passage should have been to January 7 . The confusion is all caused by several conflicting dates in the two judgments. Sinclair J. refers to the release of the service rig on January $7^{25}$ whereas Johnson J.A. refers to it as being on January $8^{26}$ and we have just seen that the reference by the latter to January 11 in the above passage probably should have been to January 7. A further conflict may arise from the following statement by Johnson J.A.:27

The learned trial judge held that because there was no production from the well ... for almost a week after the well had been completed the lease was not extended beyond the completion date which was January 8.

Who is saying that the completion date was January 8? If Johnson J.A. is paraphrasing the judgment of Sinclair J. then the date is in error. If, on the other hand, he is saying himself that the completion date was January 8 , first, the suggestion that the meaning of "completion" has been extended must be discounted and, secondly, one must ask whence came the date. Why was it not January 7 also? It is submitted that subsequent passages in the judgment of Johnson J.A. prefer the view that the meaning of "completion" has not been extended to include the steps taken between January 7 and January 11 or 13. His Lordship stated the problem in the following terms: ${ }^{28}$

[G]iven a ready market for oil, does the combined effect of these clauses require that production be taken the very moment that the well has been completed?

The negative answer to this question implies that completion and production are distinct stages and that there may be a gap between the two. It is reasonable to conclude, therefore, that "completion" in clause 12 does not include steps taken between the date on which a well is first capable of production and the date on which it actually goes on production.

The second possibility is that the meaning of the phrase "is produced" in clause 2 has been expanded to include such steps. However, there is nothing in the judgment which would appear to support this view. Rather, the repeated inference that completion and production may be separated by a time interval impliedly rebuts the suggestion.

This leaves the third possibility which is that a genuine time gap, not disguised by the expanded interpretation of any words in the lease, may exist. It is submitted that this is the correct view and that it has far-reaching implications. Johnson J.A. said: ${ }^{29}$

In interpreting these clauses, we must keep in mind the realities of the situation and the purposes which are contemplated by the lease. Among these are: (1) A well, when drilled to formation, will usually require further work to be done to obtain production, as that word is understood in the industry; (2) A tank battery to store the oil must be constructed and connected to the well; and (3) Production must be maintained to the extent permitted by its oil quota as set by the Conservation Board. Considering the effect to be given to par. 2 of the lease, the question is

\footnotetext{
34 (1970) 74 W.W.R. 324 at 331.

2s Id. at 328 .

${ }^{26}$ (1970) 75 W.W.R. 606 at 608; 16 D.L.R. (3d) 709 at 711.

27 Id. 75 W.W.R. at 609-10; 16 D.L.R. at 712. Emphasis added.

${ }^{28}$ Id. 75 W.W.R. at 610; 16 D.L.R. at 713.

29 Id. 75 W.W.R. at $611-12 ; 16$ D.L.R. at $714 \cdot 15$.
} 
not whether the well was flowing at the exact moment that the term of the lease expired (in this case when the well was completed), but whether oil can be taken and marketed so that the lessor and lessee will be entitled to the full benefit of the well's production.

Par. 12 requires that the well be drilled to completion 'with reasonable diligence and dispatch', and when the procedures which follow are found to have been done in accordance with good oilfield practices and in a reasonable time and have been done 'with reasonable diligence and dispatch' it is reasonable to conclude that the requirements of the lease have been complied with and the lease is accordingly extended for so long as production is continued from the well.

The significance of these comments for the future judicial interpretation of freehold petroleum and natural gas leases cannot be overestimated.

In the first place, it is submitted that there is no reason why, logically, the same considerations should not apply to the payment of shut-in royalties within a reasonable time of the completion of a well. As the decisions stand, such royalties must be paid prior to well completion..$^{30}$ But, why if a reasonable time gap is to be allowed in one situation should it not be allowed in another? The main concern is to see that "the lessor and lessee will be entitled to the full benefit of the well's production". ${ }^{31}$ Why should deemed production from a shut-in well be treated any differently? Again, Johnson J.A. said: ${ }^{32}$

What I consider to be of utmost importance is that the well produced and marketed its full quota of oil for the month of January and the lessor's assignee received the reserved royalty which the lessor was entitled to receive.

Similarly, it could be argued that in the case of payment of a shut-in royalty the lessor had received the royalty to which he was entitled, notwithstanding that it might not have been paid before the completion of the well. Any suggestion that a lessor may be in the position of not knowing whether the payment would be made or not could be overcome by the reasonable time requirement of the Cull case. Probably the biggest hurdle facing acceptance of such reasoning as applied to shut-in royalties would be the fact that there are Supreme Court of Canada decisions directly in point. ${ }^{33}$ It is submitted that it could be argued in answer to this that the Cull case clearly was not only correct but necessary on its facts to give effect to clause 12, that logically the same reasoning applies to the payment of shut-in royalties and therefore, to be consistent, the earlier decisions ought not to be followed.

Secondly, the comment of Johnson J.A. that the realities of the situation and the purposes of the lease are to be kept in mind ${ }^{34}$ have a wider significance. It is suggested that they indicate a move away from the previous strict interpretation applied by the Courts to petroleum and natural gas leases, an approach which has been criticised in the following terms: ${ }^{35}$

The decisions of the Courts have continued to ignore or reject the argument by lessees that petroleum leases should be viewed as a business arrangment between the parties and be interpreted in a more liberal fashion. In some instances for

\footnotetext{
${ }^{30}$ Supra, n. 13.

31 (1970) 75 W.W.R. 606 at 611 ; 16 D.L.R. (3d) 709 at 714.

32 Id. 75 W.W.R. at $612 ; 16$ D.L.R. at 714.

${ }^{33}$ Supra, n. 13.

34 (1970) 75 W.W.R. 606 at $611 ; 16$ D.L.R. (3d) 709 at 714.

ss Supra, n. 1 at $462-63$.
} 
example, lessees have lost their leases due to late performance by a mere three or four days. The Courts refuse to recognize the extreme variables which affect the scheduling of wells, the drilling days lost due to equipment failures, the delays in obtaining equipment and many other postponements caused by circumstances over which the lessee has little or no control. The Courts continue to insist that the lessee is the victim of its own procrastination by not drilling in ample time to complete its well within the primary term. Although in certain instances there is a great deal of merit to this criticism this attitude generally fails to take into consideration the justifiable reasons for 'sitting on' leases. The exploration phase of the petroleum industry is a waiting game. Good business judgment in such a high-risk business requires the lessee to wait on plays to develop in the vicinity; to drill only the most prospective structures in the early stages of exploration; to acquire lands under lease in adjacent areas before commencing drilling. It is argued that the industry should construct leases which take into consideration these exigencies, but this is just what industry has attempted to do in its evolution of the present petroleum and natural gas lease. As long as the Courts continue to construe leases so literally as to ignore the basic purpose of the lease it is doubtful that a lease will ever be drafted to protect successfully the interests and rights of the lessee.

Perhaps the judgment of the Appellate Division will prove to be the turning point in meeting such criticism.

In the Supreme Court of Canada, an appeal was dismissed with reasons delivered by Martland J.36 Essentially, they were the same as those of the Alberta Appellate Division. Martland J. said: ${ }^{37}$

Clause 2 extends the lease after the primary term for as long as drilling operations are being conducted under the authority of clause 12 and also 'during the production of oil, gas or other mineral resulting therefrom'. I do not construe this to mean that, in order to extend the lease during such production, the production must commence immediately upon the completion of drilling operations. To require that, as urged by the appellant, would deprive that portion of Clause 2, as also Clause 12, of any effect whatever. As was pointed out in the judgment of the Appellate Division, there was nothing in the evidence to suggest that, having regard to usual oilfield practice, it would ever be possible to have production at the exact moment the well was completed. It is sufficient if, following completion of the well, production is obtained from it with reasonable diligence and dispatch.

In other words, the Court accepted that a gap could exist between "completion" and "production".

The Kanstrup and Hambly ${ }^{38}$ cases were distinguished on the basis that in those decisions there was no intention to put the wells on production, nor were they put on production, whereas in the instant case there had been a bona fide intention to proceed diligently to place the well on production. ${ }^{39}$ It is respectfully submitted that, far from distinguishing the cases, this reasoning only serves to strengthen the earlier submission that the cases are not distinguishable. Surely in the Hambly case the only reason there was no such intention was due to the fact that the well could not be produced due to the absence of a market. There was nothing to suggest that the well would not have been produced if a market had been available. Furthermore, it probably would have been established, if considered relevant at the time, that the lessee had a bona fide intention of paying shut-in royalty in the event that the well was not produced. Again, why should a bona fide intention to produce suffice whereas a bona fide intention to pay shut-in royalty will not, especially when it is remembered that under this type of lease when shut-in royalty is paid, then the well in respect of which it is paid

\footnotetext{
${ }^{36}$ [1971] 3 W.W.R. 28; 20 D.L.R. (3d) 360. Abbott, Judson, Hall and Laskin JJ., concurring.

${ }^{37}$ Id. 3 W.W.R., at 36-7; 20 D.L.R., at 368-69.

${ }^{38}$ Supra, n. 13.

${ }^{39}$ [1971] 3 W.W.R. 28 at 34-5; 20 D.L.R. (3d) 360 at 366-67.
} 
"shall be deemed to be a producing well hereunder and to be producing leased substances from the said lands".

It is submitted, in conclusion, that the reasons of the Supreme Court strengthen the earlier submission that if a reasonable time gap is to be allowed between well completion and production where the well is actually produced, then logically the same principle should apply where the well is not produced but shut-in royalty is paid. The decision in Cull is inconsistent with the Kanstrup and Hambly decisions. As the Cull decision was obviously correct when considered in the light of its facts, it is to be followed in preference to the earlier decisions. Therefore, a reasonable time should be allowed between well completion and payment of shut-in royalties.

\section{The Ballem Case}

The decison of the Appellate Division of the Supreme Court of Alberta in Texas Gulf Sulphur Company v. Ballem ${ }^{40}$ has been affirmed by the Supreme Court of Canada. ${ }^{41}$ Thus, the dictum of Porter J.A. in Canadian Fina Oil Limited v. Paschke $e^{42}$ to the effect that payment of delay rentals by mailed cheque was insufficient compliance with the terms of the lease has been confirmed to be obiter. Perhaps we will now witness the picturesque possibility of a letter being mailed "containing a cheque to be borne by some primitive means of transportation from remotest Africa or the interior of China, while the grantor [waits] unaware of his rights and unable to protect them in the swiftly changing circumstances which might destroy or enhance them overnight." 43

\section{The Modde Case}

Finally, in relation to the termination of leases due to late payment of delay rentals, it may be interesting to note briefly the decision of the Supreme Court of Canada in Modde v. Dominion Glass Co. Ltd.44

The action arose under the Ontario Gas and Oil Leases Act, ${ }^{45}$ and concerned the late payment of annual delay rental within the primary term of an "unless" type of petroleum and natural gas lease. Section 2 (1) of the Act provides:

2.-(1) Where the lessor of any land or any other person having an interest in such land or any person authorized by such lessor or other person alleges,

(a) that a lessee has made default under the terms of a gas or oil lease affecting the land in that he has failed to commence to drill or has failed to complete the drilling of a well for natural gas or oil and has failed to pay rentals in lieu thereof; or

(b) that a lessee has made default under the terms of a gas or oil lease affecting the land, other than a default specified in clause $a$, and

(i) that the default has continued for a period of two years, or

(ii) that, the default having continued for a period of less than two years, the lessor has given notice in writing to the lessee specifying the default alleged and requiring the lessee to cure the default within thirty days of the giving of the notice, and that the lessee has not cured the default within such thirty days,

\footnotetext{
so (1970) 72 W.W.R. 273; (1971) 17 D.L.R. (3d) 572, allowing an appeal from thejudgment of Riley J. (1969) 70 W.W.R. 373. The decision is commented on in Currie, supra, $n$. 1 at 467-68.

4 [1971] 1 W.W.R. 560; (1971) 17 D.L.R. (3d) 640.

12 (1957) 21 W.W.R. 260 at $264-65$.

43 Id. at 265.

41 (1967) 63 D.L.R. (2d) 193.

45 R.S.O. 1970, c. 188.
} 
such lessor or other person may apply, upon affidavit, to a judge for an order declaring the lease void and, if the lease or any assignment or transfer thereof is registered, vacating every such registration.

The Court held that there were two requirements necessary to bring the jurisdiction of the County Court, in which the application for a declaration that the lease was void was made, into play. There must be both a default by failing to commence the drilling of a well and a failure to pay rentals in lieu thereof. In the case at bar these requirements had not been satisfied as delay rental had been paid and accepted prior to the application..$^{46}$

This was sufficient to dispose of the appeal but the Court went on to consider a dictum of the Court of Appeal decision that there could be a waiver of a default notwithstanding the well-known authorities that where there is no duty under a lease, there is no breach of any obligation and hence there cannot be a waiver. ${ }^{47}$ However, Section 2 of the Ontario Act specifically refers to a failure to commence a well, or to pay rentals in lieu thereof, as a "default". Spence J. said:48

If it is a default then, of course, it may be waived and, in my opinion, the learned County Court Judge was correct in his view that it had been waived [by acceptance of the delay rental].

While this aspect of the decison was clearly obiter and also is restricted to applications under the Act, it provides an interesting comparison with the position in the Western Provinces.

\section{ESTOPPEL}

\section{The Weyburn Case}

The most significant chapter in the past year in the continuing story of the estoppel cases was the decision of the Supreme Court of Canada in Sohio Petroleum Company v. Weyburn Security Company Limited. ${ }^{49}$ In this case, it will be recalled that the lease was held to have terminated on the authority of Canada-Cities Service Petroleum Corp. v. Kinninmonth. ${ }^{50}$ This finding of the trial court was not seriously disputed. The major issue was the appellant's argument that the respondent lessor was estopped from denying the validity of the lease by virtue of certain representations. The words and conduct relied upon as constituting the estoppel were: ${ }^{51}$

(1) The respondent had called upon Sohio to drill an offset well, in accordance with the requirements of the lease, which well was drilled.

(2) Sohio, at the request of the respondent, had paid seven-eighths of the mineral taxes imposed on the leased lands, which was a requirement of the lease.

(3) Sohio had paid, and the responident had accepted, royalties based upon the production from the leased lands.

(4) The respondent had permitted Sohio to enter a pooling unit, in-

to (1967) 63 D.L.R. (2d) 193 at 196.

${ }^{17}$ E.g., East Crest Oil Co. v. Strohschein (1951-52) 4 W.W.R. 553; Langlois v. Canadian Superior Oil of California (1957) 23 W.W.R. 401.

40 (1967) 63 D.L.R. (2d) 193 at 197.

19 (1970) 74 W.W.R. 727; (1971) 13 D.L.R. (3d) 340.

so (1964) 47 W.W.R. 437; [1964] S.C.R. 439.

31 (1970) 74 W.W.R. 626 at 630; (1971) 13 D.L.R. (3d) 340 at 344. 
volving the leased lands, which, under the lease terms, Sohio would have had the right to do without the respondent's consent. As has been noted previously, the distinguishing feature on these facts was the existence of positive acts or demands by the lessor on the lessee after the lease had terminated.52 The Court of Appeal, however, found that even if the abovementioned words and conduct did amount to representations, which was not decided, then the plea still failed because Sohio at no time acted upon them to alter its position, but rather had acted in consequence of its own mistaken belief that the lease had not terminated, which position it had adopted "prior to and apart from any alleged representation on the part of [Weyburn] and could not therefore have been induced thereby".53 Similar reasoning was applied to the plea of promissory estoppel. ${ }^{54}$ Now, the Supreme Court has affirmed the decision of the Court of Appeal for the same reasons. Martland J. delivering the judgment of the Court, said:55

I agree with the reasons of the Court of Appeal. It is quite clear that the actions of Sohio did not result from representations or conduct of the respondent. They were taken because Sohio, as well as the respondent, was unaware of the fact that the lease had come to an end before they were taken. In these circumstances, estoppel could not be established, and there is no suggestion that a new lease had been created.

It is respectfully submitted that no other conclusion was open on the facts. Clearly, Sohio's belief that the lease was still in effect was adopted as from the moment the primary term expired. Otherwise, surely it would not have proceeded to complete the well and place it on production. The primary term expired on October 27, 1959, and the first well was brought into production in November or early December, 1959.56 It was not until January, 1960, that any royalties were paid and accepted and more than two further months passed before the demand to drill the off-set well was issued by Weyburn. ${ }^{57}$ There cannot be much doubt that the imere acceptance of royalty payments can never constitute an estoppel by itself. This means that the well was completed and produced, obviously involving considerable expenditure, between the time the lease expired and the date of the first alleged representation seriously relied upon-the demand for the off-set well. In other words, more than five months elapsed during which Sohio can have proceeded on no other basis than that it had formed the mistaken belief that the lease was still in force.

The conclusion which necessarily follows is that all the actions allegedly undertaken by Sohio on the basis of the "representations" by Weyburn were undertaken in fact because it believed it was bound to do so under the lease. The alleged representations may well have confirmed Sohio's belief that the lease was still in force but they cannot have formed that belief in any causal sense because the belief must have existed before any representations, arguably sufficient to constitute any estoppel, were made. Mr. J. H. Currie has suggested that this may have been sufficient to uphold the estoppel. He said: ${ }^{58}$

\footnotetext{
s2 Supra, n. 1 at 455.

s3 (1969) 69 W.W.R. 680 at 684 ; (1970) 7 D.L.R. (3d) 277 at 281.

s4 Id. 69 W.W.R. at $685 ; 7$ D.L.R. at 281.

ss (1970) 74 W.W.R. 626 at 631 ; (1971) 13 D.L.R. (3d) 340 at 345.

so See the report of the trial judgment, (1968) 66 W.W.R. 155 at 159.

${ }^{37}$ Id.

s8 Supra, n. 1 at 457.
} 
Before the Supreme Court of Canada, counsel for Sohio argued that if in fact Sohio had answered Weyburn's demands due to a mistaken belief in the existence of the lease, it also acted because it was induced to do so by Weyburn. In other words, Sohio argued that there were two co-existing inducements: one inducement being its own mistaken belief in the existence of the lease; and the second being the demands by Weyburn, which confirmed Sohio's belief ... It is unfortunate that the Supreme Court of Canada found it unnecessary to address itself to this seemingly forceful argument.

In support of this submission he cites the following passage from Spencer Bower and Turner: 59

It is not necessary that the representation should be the sole or exclusive cause of the representee altering his position; it is enough that it is a cause of his doing so, provided that a real causal nexus is established. And where the action taken by the representee is obviously a natural consequence of his assuming the truth of the representation a prima facie inference may be drawn in favour of a causal connection without more.

It is respectfully submitted that the argument, and the authority cited in support of it, are misleading. First, while it is agreed that Sohio's belief in the existence of the lease may have been confirmed by Weyburn's demands, it is still necessary that there be "a real causal nexus", as the passage just cited indicates. Secondly, it is contradictory to speak of a belief being both confirmed and induced by the same demands. To have been induced it must not have already existed, while to be confirmed it must have existed. Thirdly, Spencer Bower and Turner cite no authority for the first part of the above passage to the effect that there may be an estoppel if the representation is a cause. The authority which is cited ${ }^{60}$ supports only the latter sentence. But, be that as it may, it is still necessary that there be a causal connection which it is submitted cannot be established where it is found that the belief necessarily existed prior to any alleged representation.

One further matter should be mentioned before attempting any assessment of the effect of this decision on the plea of estoppel. At trial, MacPherson J. upheld the estoppel. He said: ${ }^{11}$

There can, in my view, be no doubt that by demanding the drilling of the off-set well and two months later by granting the surface lease, the plaintiff was conducting itself in such a manner as to represent to the defendants that the lease was subsisting. Both acts were in accordance with its terms. There can, likewise, be no doubt that the plaintiff intended the defendants to act in accordance with the plaintiff's conduct. The plaintiff does not argue the contrary.

The defendants did act upon the plaintiff's demand for an off-set well. At the time the demand was received, the proposed well was being considered by Mr. Irby who was then divisional superintendent for Sohio at Oklahoma City. Saskatchewan was in his territory. He testified that he had doubts about the economics of the proposed well. He would have preferred to have postponed a decision on the well until the field was more thoroughly explored and delineated. His doubts were discarded when the defendants were advised that the plaintiff had, in accordance with the lease, demanded that the off-set well be drilled. Mr. Byers of Tenneco Oil Co., a partner of Sohio in the development, gave much the same evidence. I believe both. It therefore seems to me that it is now impossible for me to say that the defendants would have drilled the well without the plaintiff's demand. Perhaps they may have done so a year or five years later. Perhaps not. But the plaintiff's letter referred to the lease which required that it be commenced within six months of the completion of the Shell well.

This constitutes an altering of position on the part of the defendants. The detriment

\footnotetext{
59 Spencer Bower and Turner, Estoppel by Representation 98 (2d. ed. 1966).

${ }^{80}$ Newbon v. City Mutual Life Assurance Society Limited (1935) 52 C.L.R. 723 at 734.35.

o1 (1968) 66 W.W.R. 155 at 160.
} 
is obvious: The defendants poured $\$ 50,000$ into a well on land insecurely held. In addition they paid $\$ 662$ for the surface lease.

It is submitted that the conclusion in this passage contains an obvious error. While it was established that the doubts about drilling the off-set well held by Sohio were discarded when it received the demand from Weyburn, these doubts were not as to the validity of the lease but as to the economics of drilling the well. Rather than support the conclusion reached, the evidence cited strengthens the view that Sohio already believed the lease was still in force. The obvious conclusion why it proceeded to comply with the demand, despite its reluctance to do so for economic reasons, is that it believed it was obliged to do so under the terms of the lease which provided for the drilling of an off-set well within six months of the completion of a robber well.

\title{
2. The Future of Estoppel
}

It appears that the pleas of estoppel by conduct and promissory estoppel in relation to oil and gas leases have suffered the final demise. So far as estoppel by conduct is concerned, the Weyburn Case makes it difficult to imagine any circumstances in which the pleas could conceivably succeed. If a lessor believes his lease has expired it is not likely that he will be induced to alter this belief on the strength of any representation by conduct on the part of his lessor. If, on the other hand, he believes the lease has not expired then it seems clear on the basis of the Weyburn Case that this belief will have been formed independently of any such representations and at best will only be confirmed thereby. As already stated, this is not sufficient for the plea to be sustained.

Even if circumstances did arise where a lessee did form a belief in the continued existence of his lease on the basis of representations by his lessor, then it is submitted that a further hurdle remains to be overcome. It is well settled that the representation must be one of fact, not of law: Spencer Bower and Turner state the position in these terms: ${ }^{2}$

\begin{abstract}
A statement of fact accompanied by, or involving, an inference or proposition of law, where such inference or proposition is not distinct or severable from the statement of fact, is wholly and for all purposes a representation. But a statement of a rule, principle, or proposition of the general law, or a statement of the legal effect of facts which form the subject of another and a distinct and severable statement, or which are within the common knowledge of the parties, is a representation to the same extent only as any other statement of opinion; that is to say, it is not a statement of the fact of the law being thus, or thus, and there is no estoppel against a subsequent assertion that the law is otherwise; but it is an implied statement by the representor of the fact that the opinion expressed as to the law is actually entertained by him, or by the person to whom it is attributed.
\end{abstract}

The question of whether a representation that a lease is still in force is one of fact or of law is not free from difficulty. For example, it has been held that a statement as to a title or interest in a particular estate was one of fact, ${ }^{63}$ whereas a statement that a certain right ${ }^{7}$ of way had been extinguished, coupled with a separate statement of the facts on which the legal inference was based, has been held to be a statement of law. ${ }^{64}$ Without expressing any final opinion, this is clearly a difficult question which it has so far been unnecessary to answer in the situations with which we are concerned.

\footnotetext{
62 Supra, n. 59 at 36.

ws Cooper v. Phibbs (1867) L.R. 2 H.L. 149.

of Legge v. Croker (1811) 1 Ball \& B. 506.
} 
Promissory or equitable estoppel, it would appear, has been finally dispensed with in relation to oil and gas leases by the decision of the Supreme Court of Canada in the Hambly Case. ${ }^{65}$ While this form of estoppel may not necessarily be confronted with the requirement that the representation be one of fact, ${ }^{66}$ it seems clear that it does require an existing relationship between the parties, whereas inevitably in the type of situation with which we are concerned, the lease, and along with it the necessary relationship, has terminated.

That leaves only the possibility of estoppel by deed. The only decision on oil and gas leases where the lessee has succeeded in upholding an expired lease is Canadian Superior Oil Ltd. v. Murdoch ${ }^{67}$ There, it will be recalled, the ratio of the decision was that a contractual basis had been agreed upon between the parties, and the Court thus found it unnecessary to resort to estoppel, at least by name. The difference between the two is difficult to discern and it is interesting to note that the Murdoch decision was cited as authority, although obiter, for estoppel by deed in Paramount Petroleum and Mineral Corporation Ltd. v. Imperial Oil Ltd.68

However, semantics aside, a serious problem could arise even in relation to this kind of estoppel. The clauses usually relied upon in these cases take the form of ratifying that the lease is still in effect. ${ }^{69}$ The so far unanswered question is: What part of the lease is in effect? Does it continue as though the lessee has proceeded to the secondary term under the provisions of the lease which, by the very nature of the problem, he has not? Or, do such words, especially "full force and effect", continue the lease as though in the primary term with a corresponding right to "validly" proceed to the secondary term? At one stage it appeared that these questions would have to be faced by the Cull Case where estoppel by deed was upheld at trial. ${ }^{70}$ However, it was not necessary for the Appellate Division or the Supreme Court to deal with the question in view of their holding that the lease had not expired.

A further difficulty not adverted to in the Murdoch case would arise where there are intervening third party rights creating interests in land which have been protected by caveat. If the right created by ratifying agreements is contractual only, as the Court in the Murdoch case said it is, ${ }^{71}$ then it could not defeat such third party rights. Nevertheless, it must be admitted that in the Murdoch case itself, the caveats filed by Canadian Superior were continued, thus effectively giving them

s Canadian Superior Oil Ltd. v. Hambly (1970) 74 W.W.R. 356; (1970) 12 D.L.R. (3d) 247. See supra, n. 1 at 457-60.

os In Lyle.Meller v. A. Lewis \& Co.(Westminster) Ltd. [1956] 1 All E.R. 247 at 250, Denning L.J. Said:

I do not think it necessary to go into these refinements about law and fact. I am clearly of opinion that this assurance was binding, no matter whether it is regarded as a representation of law or of fact or a mixture of both, and no matter whether it concerns the present or the future. It may not be such as to give rise to an estoppel at common law, strictly so called, for that was confined to representations of existing fact; but we have got far beyond the old common law estoppel now. We have reached a new estoppel which affects legal relations.

a7 (1969) 68 W.W.R. 390, affirmed on appeal (1969) 70 W.W.R. 768. See supra, n. 1 at $460-62$.

ss (1970) 73 W.W.R. 417.

os In the Murdoch Case itself the relevant clause provided as follows:

[The lessor] does hereby ratify and confirm that the said lease is in good standing and of full force and effect.

In the Paramount Petroleum Case the relevant clause covenanted that the leases in question "still subsist without variation". In the Cull Case the clause provided:

All other terms, covenants and conditions contained in the same lease remain in full force and effect.

70 (1970) 74 W.W.R. 324.

7 (1969) 68 W.W.R. 390 at 398. 
an interest in land insofar as no subsequently acquired interests could gain priority over such caveats. We may ask how the agreement in that case, "[c]onsidered simply as a contract", ${ }^{72}$ could support the continued registration of a caveat which depends for its validity upon some interest in land..$^{73}$

\section{ACCOUNTING UNDER EXPIRED LEASES}

An interesting problem which arises where the lessee has proceeded to production on the basis that he is operating under a valid lease, but it is subsequently determined that the lease had previously terminated, has produced two different rulings in recent cases. A full discussion of the issue is beyond the scope of this article but it is felt that some reference to its existence may be valuable. Briefly stated the problem is: On what basis is a lessee to account to his lessor for production obtained after the lease has expired?

In the Paramount Petroleum Case, ${ }^{74}$ while certain of the leases were upheld, others were held to have expired on the authority of CanadaCities Services Petroleum Corp. v. Kinninmonth. ${ }^{75}$ In relation to these, Johnson J. ordered an accounting by Imperial of all leased substances taken by it. ${ }^{76}$ However, in the Weyburn Case, ${ }^{77}$ the same issue was dealt with in the following terms: ${ }^{78}$

The appellant also sought an accounting of all petroleum, natural gas and related hydrocarbons removed from the land by the respondents, or damages in lieu thereof. The court has jurisdiction to grant this relief on terms which will be just and equitable to all parties involved. The respondent, Sohio, proceeded under a mistake as to its rights, and did not knowingly take an unfair advantage of the appellant's lack of appreciation of its legal rights. The respondents were first aware that their position was challenged when the writ of summons was served upon them. At that time the revenue which they had received from the sale of the production exceeded the amount they had expended. Under the circumstances, it would appear just and equitable to order the respondents to account for all benefits from production received by them after the date of service of the writ of summons upon them.

Thus, in one case the lessee was held liable to account for all leased substances whereas in the other he was liable to account for all benefits from production only after service of the writ.

Two questions arise. First, from what date should the lessee account and secondly, on what basis should he account. It is suggested that the proper date is that on which the lease is held to have expired, as clearly the lessee is a trespasser from that point, admittedly a bona fide trespasser, but nonetheless a trespasser..$^{79}$ Insofar as the Weyburn Case held that there was no liability to account until the lessee becomes aware that his right to produce the oil is being challenged, it is respectfully submitted to have been wrongly decided. If it were right on this point, it would mean that a lessor who was lucky enough to discover early that the lease had expired would be in a favoured position to that of

72 Id.

73 The Land Titles Act R.S.A. 1970, c. 198, 8. 136.

74 Paramount Petroleum and Mineral Corporation Ltd. v. Imperial Oil Ltd. (1970) 73 W.W.R. 417.

75 (1964) 46 W.W.R. 437; 45 D.L.R. (2d) 36, affirming (1963) 44 W.W.R. 392; 42 D.L.R. (2d) 56.

76 (1970) 73 W.W.R. 417 at 434.

77 Sohio Petroelum Company v. Weyburn Security Company Limited (1970) 74 W.W.R. 626; (1971) 13 D.L.R. (3d) 340.

78 Id. 74 W.W.R. at 632; 13 D.L.R. at 345-46.

70 He is a trespasser to the mineral estate only as he will no doubt have the right to enter the property under his surface lease. 
the lessor who did not become aware of the possibility until years after the event. Yet, in each case, it would be the lessor's oil and gas which was being wrongfully produced by the lessee.

However, the date on which a lessee becomes aware of any challenge to his right to produce is relevant to the second question, viz., on what basis is he to account to his lessor for the wrongfully taken production. Here, a distinction is drawn between the mala fide trespasser and the trespasser acting "fairly and honestly in the full belief that he had a right to do what he did." 80 Where a trespasser is not bona fide he is not entitled to any deduction for the cost of severing minerals because it is not until a mineral is severed that it becomes a chattel and, thus, the subject-matter of an action for conversion. Expenses incurred after severance, when the lessee is dealing with a chattel, are deductible, as expenses necessary to make goods saleable are deductible under the normal measure of damages in actions for conversion, i.e., the market value of the goods. But those expenses incurred prior to severance are not deductible as it is not until the point of severance that a mineral first acquires any value qua chattel. To avoid the harshness of this rule, the common law developed an exception permitting a mineral trespasser to deduct the costs of severance where he had a bona fide belief in his title to the land. ${ }^{81}$ Therefore, it is submitted that a bona fide trespasser is accountable to his lessor for the value of all oil produced less expenses but, after becoming aware of any challenge to his right to produce, he will lose the benefit of the exception and be accountable without any deduction for the costs of severance. ${ }^{82}$

If these principles are correct, then in the Weyburn Case, the lessee should have been held to account for the market value of the oil produced less production and marketing costs to the date of issue of the writ ${ }^{83}$ and thereafter for the value of the oil produced less marketing costs only.

A related but separate problem arises by virtue of the fact that the lessee usually will have expended considerable amounts on well equipment which he cannot practically remove. Much of this, it is suggested, would be in the nature of a permanent improvement to the lessor's land. At common law, a bona fide trespasser had a lien for improvements made to the plaintiff's land. However, in Alberta, Section 183 of the Land Titles Act $^{84}$ provides an additional remedy:

183. (1) Where a person at any time has made lasting improvements on land under the belief that the land was his own, he or his assigns

(a) are entitled to a lien upon the same to the extent of the amount by which the value of the land is enhanced by the improvements, or

(b) are entitled to or may be required to retain the land if the court is of opinion or requires that this should be done having regard to what is just under all the circumstances of the case.

(2) The person entitled or required to retain the land shall pay such compensation as the court may direct.

Now, while the section is obviously designed to deal mainly with the

\footnotetext{
so Wood v. Morewood (1841) 3 Q.B. 440 at 441.

"Id. See also Hilton v. Woods (1867) L.R. 4 Eq. 432; Ashton v. Stock (1877) 6 Ch. D. 719; Livingstone v. Rawyards Coal Co. (1880) 5 App. Cas. 25.

82 See generally Mayne and McGregor, The Law of Damages 688 et seq. (12th ed. 1961).

s3 I.e., if we accept this as the date on which the lessee first became aware of a challenge being made to his right to produce.

st R.S.A. 1970, c. 198.
} 
familiar problem of building encroachments, it may be argued that the section could be applied in the type of situation under discussion, not only to give the lessee a lien, but to enable a court to direct the lessor to pay compensation. There is no definition of "own" in the Act, but an "owner" means "any person or body corporate entitled to any freehold or other estate or interest in land, at law or in equity, in possession, in futurity or expectancy." 85 Applying this same approach to the words "under the belief that the land was his own", it would seem that the lessee could qualify under the section.

\title{
E. DELAY RENTALS AND THE NON-RESIDENT WITHHOLDING $T A X$
}

A threatening problem under the "unless" type of petroleum and natural gas lease has been the application of the non-resident withholding tax to delay rental payments. In view of the necessity for payment of the proper amount, the dilemma has been how to comply with both the terms of the lease and at the same time Part III of the former Income Tax Act ${ }^{86}$ which required that a person paying to another person an amount on which income tax was payable under that Part should withhold the tax and remit it to the Receiver General.

The only case in which the problem appears to have been raised is the Paramount Petroleum Case $e^{87}$ where it was alleged that by withholding the 15 per cent tax payable under Section 106 of the Income Tax Act, the lessee had failed to comply with the provisions of the lease. However, Johnson J. disposed of the problem in the following passage:88

\begin{abstract}
One further matter raised by Paramount and Bison requires consideration. They now contend that because Imperial withheld 15 per cent non-resident tax from the annual acreage payments to Morris Stern it thereby failed to comply with the provisions of the lease to pay the lessor the stipulated annual acreage rental each year. At the time of the oral argument before me this issue was not raised by learned counsel for the plaintiffs. It was agreed that item 27, of the agreed statement of facts, supra, would be added to the statement of facts. However, its significance was not indicated. Later, when written argument was received on behalf of the plaintiffs, this issue was raised for the first time. At no time was an amendment sought to the statement of claim to plead the necessary facts to raise the issue, and since the action was commenced in November, 1962, it is quite obvious that this contention is merely an afterthought on the part of the plaintiffs. To permit the plaintiffs' contention to be given effect now, even if it were well founded, would be most unjust since the defendant has had no opportunity to meet this contention with appropriate evidence or by agreement to facts in connection with the issue. Accordingly on this ground alone I would refuse to give effect to the plaintiffs' submission.
\end{abstract}

If he were wrong in this conclusion, His Lordship was prepared to find estoppel by deed, as already mentioned. ${ }^{9}$

Some comfort to lessees was previously available under a ruling of the Department of National Revenue in 1958 that in its opinion delay rentals were capital receipts and, therefore, not subject to the 15 per cent withholding tax.90 This ruling was confirmed by the Department

\footnotetext{
os Id. 8.2 (emphasis added).

so R.S.C. 1970, c. I-5. Cf. Tax Reform Bill 1971, c-259, s. 215.

87 Paramount Petroleum and Mineral Corporation Ltd. v. Imperial Oil Ltd. (1970) 73 W.W.R. 417.

as Id. at 432-33.

- Supra, at 404.

\$o Letter from Department of National Revenue to Pan American Petroleum Corp., July 14, 1958.
} 
in $1966^{91}$ and again in 1967.92 Now, however, the Department has completely reversed its interpretation without acknowledging the slightest embarrassment in view of its earlier rulings. The Department has ruled that, in its view, delay rental payments are similar to rent within the meaning of Section 106 of the Income Tax Act and thus subject to the withholding tax. All such tax was to be withheld on payments made on or after January 1, 1970.93

The effect of withholding the tax on the lease is therefore as unclear as ever. Perhaps if the problem is raised squarely some support for the lessee's position may be found in the provision in Section 109 of the Income Tax Act that the tax is to be remitted "on behalf of the nonresident person on account of the tax." Possibly these words could give rise to a statutory agency relationship between lessor and lessee for the amount of the tax. In the meantime, it would appear that in those cases where an "unless" lease does not provide for such deductions to be made, the safest course is to pay the full amount of the rental to the lessor and the 15 per cent tax. In view of the amounts likely to be involved, this would constitute cheap title insurance. It is understood that the practice is in fact adopted by some companies. A simpler solution is to provide in the lease for a Canadian depository to avoid the necessity of withholding the tax in the first place.

\section{F. THE NATURE OF ROYALTY INTERESTS}

There have been few developments in this area since the topic was discussed at the Annual Seminar of the Foundation in 1970.94 However, a few comments on matters not discussed then hopefully will be of some interest.

\section{The Bensette Case}

The decision of the Saskatchewan Queen's Bench in Bensette and Campbell v. Reece ${ }^{95}$ is under appeal to the Court of Appeal. Briefly, it will be recalled that in that case the Court had to determine whether the interest granted by a royalty agreement was an interest in land or a mere contractual right. The relevant clause provided: ${ }^{96}$

The party of the First Part covenants and agrees with the parties of the Second Part in consideration of the sum of One Dollar of lawful money of Canada to it in hand paid, the receipt whereof is hereby acknowledged, to give, grant, bargain, sell, assign and transfer and by these presents doth give, grant, bargain, sell, assign and transfer unto the parties of the Second Part a six per cent (6\%) royalty in all the oil, gas, petroleum and mineral oils, mines and minerals acquired by the party of the First Part by the said agreement and the said several assignments which may be found in, under or upon the said lands.

Disbery J. found that these words created an interest in land. He said: ${ }^{97}$

Giving to the precise and unambiguous words "doth give, grant, bargain, sell, assign and transfer" used in P. 26 their ordinary and natural sense and meaning I can come

2 Letter from Department of National Revenue to Canadian Petroleum Association, November $15,1966$.

92 Letter from Department of National Revenue to Canadian Petroleum Association, May 19, 1967.

93 Letter from Department of National Revenue to Canadian Petroleum Association, December 30, 1969, con. firmed by subsequent letter, January $26,1970$.

94 See Currie, supra, n. 1 at 476 et seq. See also, Davies, Problems in Relation to Overriding Royalty Interests in Oil and Gas, (1972) 10 Alta. L. Rev. 232.

is (1969) 70 W.W.R. 705.

96 Id. at 708.

97 Id. at 712. 
to no other conclusion than that Burke by using them intended to sell and transfer to Bensette and Graham and did sell and transfer to them a fractional six per cent of its minerals in the said lands, and that consequently Graham and Bensette became the owners thereof. I therefore find that the plaintiffs obtained an interest in land which entitled them to register a caveat against the certificate of title to the said land.

Some certainty may have been added to this difficult problem of determining whether or not a royalty interest is an interest in land had he relied for his conclusion on the words "which may be found in, under or upon the said lands". It is submitted that these words, more than those relied upon by the learned judge, more clearly indicate that the parties intended to sell and purchase an interest in the minerals as part of the land, particularly when compared to such alternative words as "produced, saved and sold"98 which equally indicate an intention to create an interest in the substances being dealt with after severance, i.e., as chattels.

However, notwithstanding the finding that the plaintiffs acquired an interest in land, their claim for a declaration that they were entitled to a six per cent royalty on all oil, gas, petroleum, mineral oils, mines and minerals in the defendant's title was dismissed on the ground that the caveat protecting their interest had lapsed. ${ }^{99}$

Both findings have been challenged on appeal. The plaintiff appellant has challenged the findings of the trial judge on all issues except the holding that the plaintiff obtained an interest in land.100 However, the more interesting issues are raised by the defendant respondent's Notice of Intention to Vary which seeks a variation of the trial judgment insofar as it held that the plaintiffs obtained an interest in land and insofar as it held that the agreement gave to the plaintiffs an interest in the mines and minerals. The Notice also raises issues of estoppel and alleges that the agreement violated the rule against perpetuities.

\section{The Emerald Case}

The decision of the Appellate Division of the Supreme Court of Alberta in Emerald Resources Ltd. v. Sterling Oil Properties Management Ltd. ${ }^{101}$ has been affirmed by the Supreme Court of Canada. ${ }^{102}$ As with the Bensette Case, the decision throws little light on the question of whether royalties are an interest in land or mere personalty.

\section{The Keyes Case}

One recent case dealing with the nature of royalty interests has been appealed to the Supreme Court of Canada and, as with the Bensette Case, should provide clarification of some of the difficulties involved in the question of whether subsequent assignees are bound by reservations or royalties. In Keyes v. Saskatchewan Minerals, ${ }^{103}$ one Harvie was the holder of two alkali leases from the Crown in right of Saskatchewan. In 1943, Harvie granted an option to Keyes giving him the right to acquire by purchase Harvie's rights in and under the two leases. Sub-

39 Cf., Emerald Resources Ltd. v. Sterling Oil Properties Management Ltd. (1969) 3 D.L.R. (3d) 630.

90 (1969) 70 W.W.R. 705 at 712 et seq.

100 See Notice of Appeal Number 1966, Saskchewan Court of Appeal. I should like to thank Mr. J. L. Robertson, Q.C., counsel for the plaintiffs, for providing me with copies of both the Notice of Appeal and the Notice of Intention to Vary.

101 (1969) 3 D.L.R. (3d) 630. See, Currie, supra, n. 1 at 477 et seq.

102 (1971) 15 D.L.R (3d) 256.

103 (1970) 12 D.L.R. (3d) 637. The decision of the Court of Appeal has now been reversed by the Supreme Court of Canada with a strong dissenting judgment by Laskin J., [1972] 2 W.W.R. 108. 
sequently, on June 3,1948, Keyes entered into an agreement with Astral Mining and Resources Limited which provided, in part, as follows: 104

Whereas the said Keyes is entitled to a twenty-one year lease from the Hudson's Bay Company covering 160 acres at the north end of Lake Ingebright, Saskatchewan, known as the south-east quarter of Section 26, Township 16, Range 25, West of the Third Meridian, subject to an annual rental of $\$ 660.00$, and the payment of a base production royalty of $12 \frac{1}{24}$ per ton for salt removed from the concession.

And Whereas the said Keyes has arranged to transfer to Astral an option to take over a lease dated the 30th day of January, 1948, entered into between the Minister of Natural Resources and Industrial Development for the Province of Saskatchewan and Eric Lafferty Harvie, of the City of Calgary, in the Province of Alberta, the said Harvie representing himself and Messrs. Leo H. Miller and C. J. Ford, the said lease being for a term of twenty years renewable for similar periods at a rental of 254 an acre per year with a royalty clause reading as follows:

"AND ALSO RENDERING AND PAYING therefor unto the Lessor such royalty at such times and in such manner as may from time to time be prescribed by or pursuant to The Mineral Resources Act or the Regulations made thereunder." 1. Keyes hereby agrees to assign and doth hereby assign all his right, title and interest in the Hudson's Bay leasehold and the salt and other deposits therein to Astral Mining \& Resources Limited, as Purchaser;

3. The consideration to be paid by Astral Mining and Resources Limited to Keyes for the sale and assignment of all of the above property, rights and concessions shall be,-

(a) The sum of Eighty-seven Thousand Five Hundred Dollars $(\$ 87,500.00)$ to be paid and satisfied by the issue and allotment to Keyes or his nominees in writing named of Three Hundred and Fifty Thousand $(350,000)$ shares of the capital stock of Astral Mining \& Resources Limited, fully paid and non-assessable; and

(b) a royalty of twenty-five cents $(25 \%)$ per ton on all anhydrous salt produced and sold from the said leasehold property; and

(c) a base production royalty of one per cent (1\%) on all oil and gas won or derived by Astral Mining \& Resources Limited from any of the said leasehold premises or lands.

4. The said Keyes warrants and declares that all taxes, rentals and other charges owing under said lease with the Hudson's Bay Company have been or will be paid up to the date of actual transfer of the said leases to Astral Mining \& Resources, Limited.

Although an assignment was not specifically mentioned, for reasons on which it is not necessary to elaborate here, the Court held that this agreement operated as an assignment from Keyes to Astral of the former's option from Harvie to purchase one of the leases, Lease A4010. No assignment of the option to purchase the other lease, Lease A163, was ever executed but it was established that Astral had agreed verbally to pay to Keyes a royalty on production under this lease. ${ }^{105}$

The next step was that on June 30,1948 , Harvie, as lessee, assigned separately both leases to Astral. No reference was made in these assignments of the option granted to Keyes. Then, by assignment of September 6, 1961, Astral assigned all its right, title and interest in and to both leases to Saskatchewan Minerals. Keyes claimed to be entitled as against Saskatchewan Minerals to the royalty of 254 per ton which he had reserved under the assignment of his option to Astral. At trial it was held that he was so entitled.106

On appeal, this finding in relation to Lease A4010 was upheld but

\footnotetext{
104 (1970) 12 D.L.R. (3d) 637 at 640-41.

los Id. at 641-42.

108 Unreported judgment of Bence C.J.Q.B.
} 
overruled in relation to Lease A163. Maguire J.A. for the court, said:107

The term 'royalty' may be used in various senses and with different meanings. It may be used merely to indicate a basis for computing compensation for consideration given, and thus establish a contractual right to recover that compensation. It is commonly used to indicate a reservation by the owner of land with mineral rights on the granting of a 'lease' or right to search for and remove the mineral in question. When so used, the reservation or royalty binds, not merely the lessee, but also any assignee of the lessee. It has been referred to as a reservation, operating as an exception out of the demise: Spooner v. M.N.R., [1931] 1 D.L.R. 723, [1930] Ex. C.R. 229; reversed [1931] 3 D.L.R. 136, [1931] S.C.R. 339.

The nature of the reservation of a royalty on the assignment of an option to obtain a mineral lease, as in the present instance, has caused me concern.

He then examined the terms of Lease A4010 and held, on the authority of the Berkheiser case, ${ }^{108}$ that it granted a profit a prendre. After rejecting certain American authority on the question, ${ }^{109}$ he proceeded:110

the learned trial Judge held that under and by virtue of the option, Keyes obtained an interest in the land. I agree: Frobisher Ltd. v. Canadian Pipelines \& Petroleums Ltd. et al., 21 D.L.R. (2d) 497, [1960] S.C.R. 126.

In result, I am of the opinion that, if one having an interest in the 'land' grants an assignment or lease of that interest, reserving a royalty, payment of that royalty binds a subsequent assignee.

I agree with the learned trial Judge that Keyes, holding an option to acquire the lessee's rights in and to Lease A4010, had an interest in the land, and that an assignment thereof, with reservation of a stated royalty, created or reserved an interest binding upon the assignees and its subsequent assignee, the appellant herein.

However, with respect to Lease A163, the position was different as there had been no assignment of this lease by Keyes to Astral. At best, here there was merely a contractual promise by Astral which could not bind Saskatchewan Minerals as assignee.111

In view of the fact that the Supreme Court has now delivered judgment, 112 it is not proposed to discuss the merits of the decision beyond stating generally that it contains many difficulties, not the least of which is the basis on which it was found that the option from Harvie to Keyes had in fact been granted when the option itself was not produced at the trial. 113

A subsidiary aspect of the decision is also of interest. The Appeal Court held that in granting the option to Keyes, Harvie did not "assign, transfer or sublet the rights described in his lease or any part thereof" within the meaning of the relevant regulations requiring the approval of the Minister. ${ }^{114}$

\section{The Hayduk and Prudential Cases}

Two not so recent cases dealing with royalties should be mentioned briefly. In Hayduk v. Waterton, ${ }^{115} \mathrm{~K}$. transferred his land to his son A. in favour of $\mathrm{A}$. and his three sisters and subject to a "liferent" to $\mathrm{K}$.

107 (1970) 12 D.L.R. (3d) 637 at 643-44.

103 Berkheiser v. Berkheiser [1957] S.C.R. 387; (1957) 7 D.L.R. (2d) 721.

107 Cited in (1970) 12 D.L.R. (3d) 637 at 644.

110 Id. at 645.

11. Id. One might ask what consideration there was for this "contractual promise" in the absence of any assignment of the lease.

112 See supra, n. 103.

It3 (1970) 12 D.L.R. (3d) 637 at 643.

i11 Id. at 645 .

11 (1968) 64 W.W.R. 641. 
and his wife. An oil and gas lease was subsequently granted by A. with $\mathrm{K}$.'s consent and later affirmed by the three sisters. A dispute arose as to K.'s entitlement to royalties under the lease. The Supreme Court of Canada held 116 that it was clear from the acts of the parties that they had intended the word "liferent" to include all the fruits of the land, including oil royalties, notwithstanding that such royalties were not in the contemplation of the parties at the time of the agreement. The trial judge's finding of fact that there was an agreement among all the parties that $\mathrm{K}$. was to receive the royalties during his life could not be disturbed.117 However, the Court appears to have acknowledged that normally under a life tenancy, the life tenant is not entitled to royalties, as such receipts are capital and not income. ${ }^{118}$

In Prudential Trust Co. Ltd. v. National Trust Co., ${ }^{119}$ the Court was called upon to deal with the question of whether an entirety clause applied to a disposition of royalty by a lessor. At trial it was held that the clause did apply, but on appeal, the matter was returned for trial on the basis that not all parties affected by the action were parties to it, and on the basis that it was unclear from the evidence what part, if any, of the lands in question were included in a unitization agreement dealing with lands in the area. The interesting aspect of the decision is found in the following dictum of Smith C.J.A.:120

It will be observed that the so-called entirety clause includes the following phrase: If the leased premises are now or shall hereafter be owned in severalty or in separate tracts the premises nevertheless shall be developed and operated as one lease...

In the agreed statement of facts it is stated:

On June 1st, 1959, a Royalty Owners' Unitization Agreement, a copy of which is annexed hereto as Exhibit 17, to which the Plaintiff Prudential, the Defendant National and the said John Brouwer were parties, subject to their dispute as to the distribution of royalties, became effective whereby the spacing unit in respect of the well on LSD 8 of Section 5 was then deemed to be productive and royalty payable in respect thereto.

It appears to me that the question may arise, which has not been argued before us, whether the execution of the royalty owner's unitization agreement by the appellant, the respondent and Brouwer, has the effect of providing that the portion of the lands consisting of the N.E. $1 / 4$ and the fractional parts of the N.W. $1 / 4$ and S.W. $1 / 1 /$ of sect. 5 and the portion of the lands consisting of the S.E. $1 / 4$ are thenceforth not to be "developed and operated as one lease". In other words the question may arise whether the so-called entirety clause has been abrogated by the unitization agreement.

\section{G. ACQUISITION OF AND COMPENSATION FOR SURFACE RIGHTS}

The whole subject of expropriation is currently being studied by the Alberta Institute of Law Research and Reform. ${ }^{121}$ In the meantime, decisions under existing legislation continued to make a substantial contribution to the law reports during 1970-71.

\footnotetext{
116 Cartwright C.J., dissenting on the ground that the evidence did not establish any agreement entitling K. to receive royalties during his life.

117 (1968) 64 W.W.R. 641 at $652,658-59$

118 Id. at 652.

119 (1965) 55 D.L.R. (2d) 272, allowing an appeal from (1964) 47 D.L.R. (2d) 596.

120 (1965) 55 D.L.R. (2d) 272 at 277-78, Porter J.A., concurring (Emphasis added).

121 The Institute so far has produced Working Papers on Principles of Compensation and on Procedure.
} 


\section{The Swan Swanson Case}

The litigation in Dome Petroleum Limited and Pan American Canada Oil Company Ltd. v. Swan Swanson Holdings Ltd. ${ }^{122}$ has produced a sequel. ${ }^{123}$ It will be recalled that this was an appeal from a decision of the Public Utilities Board declining jurisdiction to consider the width of a pipeline right-of-way. The Appellate Division of the Supreme Court of Alberta, however, held that the Board did have this jurisdiction following which the parties made full submissions to the Board as to the width and location of the pipeline. During this hearing, the Board made the following rulings: ${ }^{124}$

1. It has no jurisdiction to change the route or site of the pipeline applied for by Dome, and can consider only the rights and the land described in the application.

2. It has jurisdiction to differentiate between the width of right-of-way necessary or essential for the construction of a pipeline, and the width necessary or essential for its subsequent maintenance and servicing.

3. It has jurisdiction to take into account the following matters in determining what width of right-of-way is necessary or essential for the purpose applied for:

(a) The proposed or actual location of the pipeline within the desired right-of-way.

(b) The presence of an existing right-of-way and the location of a pipeline or structure therein.

(c) The kind or nature of the land to be expropriated and the use that is being made of it by the owner.

(d) The costs of constructing and maintaining different kinds and sizes of pipelines over varying kinds of land.

It then proceeded to reduce the right-of-way width from 50 to 35 feet. Swan Swanson appealed to the Appellate Division of the Supreme Court of Alberta. ${ }^{125}$

The Board's rulings were upheld and the appeal dismissed. Clement J.A. Smith C.J.A. concurring, ${ }^{126}$ said that, when an interim order was made giving a right to enter for the purpose of constructing a pipeline and the pipeline was then constructed, it was not practical to propose, as Swan Swanson did, that the Board could subsequently on an application for expropriation hear evidence that would lead it to conclude that the pipeline should be located at some other place in the interests of the landowner. The Board had no jurisdiction to consider or weigh the interests of the landowner in relation to the desire of the applicant to expropriate specific land. ${ }^{127}$

The particular position taken by Swan Swanson was that some interest in a contiguous right-of-way, that of Pembina or Trans-Mountain, could be expropriated to some extent for the purposes of Dome's application. Having already held that the Board did not have jurisdiction to so change the pipeline route, it was not necessary to proceed further. However, in relation to Trans-Mountain, His Lordship pointed out that, in any event, no interest held by Trans-Mountain could be expropriated by provincial authority as it was governed by the provisions of The National Energy Board Act. ${ }^{128}$ But, the position with respect to

\footnotetext{
122 (1969) 72 W.W.R. 6; 9 D.L.R. (3d) 376.

12 Dome Petroleum Limited and Pan American Canada Oil Company Ltd. v. Swan Swanson Holdings Ltd. (No. 2) [1971] 2 W.W.R. 506.

124 Public Utilities Board of Alberta Order No. 29729, February 10, 1970, reported in [1971] 2 W.W.R. 506 at 507.8.

125 Supra, n. 123.

126 McDermid J.A. delivered a separate judgment.

127 [1971] 2 W.W.R. 506 at 511-12.

128 R.S.C. 1970 , c.N.6.
} 
Pembina was different and the Board would have jurisdiction to grant an interest in Pembina's right-of-way if Dome should apply for expropriation of any such interest. 129

Two other matters arising out of the judgment should be mentioned. Although clearly obiter, Clement J.A. said: ${ }^{130}$

I should observe that there may be cases in which the right-of-way location selected by an applicant is so unreasonable in the circumstances, and the interests of the landowner are so unnecessarily and harshly affected, that a question may arise as to whether the power of expropriation is being exercised in good faith. Such a case could attract the application of other principles, and I reserve consideration of it for an occasion on which it arises.

The other matter related to the reduction of the right-of-way from 50 to 35 feet. Both parties contended that in so doing the Board had considered matters of fact not proper for this purpose. His Lordship held that the Board could consider only the necessary or essential requirements of the applicant. He continued:131

The necessary and essential requirements of the applicant may well be affected by costs of construction and maintenance having regard to the nature of the land to be expropriated as well, in my view, as by the intended location of the pipeline within the desired right-of-way and the presence of an existing right-of-way and the location of a pipeline or structure within it. I do not think that the use that is being made by the owner of the land desired to be expropriated is relevant, as that is more a matter for compensation: however, such use does not appear to have been taken into account by the Board in making its decision.

Both parties have appealed to the Supreme Court of Canada. Dome contended in its Notice of Cross Appeal ${ }^{132}$ that the Board should have granted the width of right-of-way necessary to construct the pipeline rather than the width it found necessary merely to operate, maintain, inspect, remove, replace, reconstruct and repair the pipeline. It also claimed that there is no jurisdiction in the Board to redetermine the width of right-of-way upon final application, having already determined such width on the interim application.

\section{The Horne Case}

Similar questions were involved in Imperial Oil Limited v. Horne. ${ }^{133}$ Kirby J. held that the Swan Swanson Case (No. 1) was determinative as to the jurisdiction of the Board with respect to the extent and area of the lands necessary or essential to the pipeline, but not with respect to the location of the pipeline. He said: ${ }^{134}$

In my opinion the effect of the provisions of sec. 5(2)(a)(i) of The Pipe Line Act, 1958, considered in conjunction with sec. 9(6), and with sec. 32 of The Expropriation Procedure Act, is to confer an absolute discretion on the Minister with respect to the location of a pipeline, which is not subject to review.

\section{The Velander Case}

Jurisdictional problems in relation to applications for rights of

\footnotetext{
129 [1971] 2 W.W.R. 506 at 513 .

130 Id. at 513.

131 Id. at 514.

132 I should like to thank Messrs. Saucier, Jones \& Co. for providing me with copies of the Notices of Appeal and Cross Appeal and also the unreported reasons of the Appellate Division as the decision had not been reported at the time of writing. Leave to appeal dismissed, Supreme Court of Canada Bulletin, October 8 , 1971 at 297.

133 (1970) 75 W.W.R. 361.

134 Id. at 368 .
} 
entry have also arisen recently in British Columbia. In $R e$ Velander's Certiorari Application, ${ }^{135}$ the Board of Arbitration, on an application under Section 33 of the Petroleum and Natural Gas Act ${ }^{136}$ for right of entry to drill a well, ordered that right of entry be granted to Imperial Oil Limited "for the purposes set out in Section 18(2) of the said Act." Section 18(2) provides:

2. Subject to all other provisions of this Act and the regulations made thereunder, the holder of a permit, licence, lease, geophysical licence, or drilling reservations held under this Act has the right to the use and possession of whatever part of the surface of the location that is necessary for the purpose of exploring for, winning, and extracting petroleum or natural gas, or both, from the location.

Hinkson J. held that the Board had exceeded its jurisdiction. Under Section 33 of the Act, the Board was empowered to grant "the leave applied for." By ordering entry for the purposes set out in Section 18, the Board had gone beyond the purposes stated by the applicant and, accordingly, the order must be quashed.

\section{The Hughes Case}

The recent decision of the Alberta Supreme Court in Hughes v. Gidosh $h^{137}$ is of considerable interest. The plaintiff granted a surface lease for a well-site and access roads to Canada-Cities Service Petroleum Corp. with rentals expressed to be paid to him. Rights of entry had also been granted by the Right of Entry Arbitration Board, the orders again specifying payments to the plaintiff. The Corporation filed the orders and a caveat in respect of the lease with the Land Titles Office. Subsequently, Hughes sold the land to one Biever, retaining the moneys payable under the lease and the Board orders. Biever executed an agreement assigning all such payments to Hughes but no caveat was filed in respect thereof. Biever subsequently sold the property to the defendants who were told of the agreement between Biever and Hughes assigning the rentals to Hughes. The defendants claimed to be entitled to the rentals under both the orders and the lease.

Greschuk J. held that the plaintiff continued to be entitled to the rentals. He said:138

The conclusion therefore that I draw from these sections [of the Land Titles Act] is that the registration of the orders and caveats by the Corporation gave notice to all the world, including the co-defendants, of the rights of the Corporation and the plaintiff under the orders and of the beneficial interests of the Corporation and of the plaintiff in the leasehold interest. The registration of the orders and the caveats prevented the acquisition or the bettering or increasing of an interest in the said lands, legal or equitable, in derogation of the claim of the Corporation and, by implication, of the rights of the plaintiff under the orders and in the leasehold interest as lessor. As soon as the orders and caveats were registered by the Corporation it charged the certificate of title of the co-defendants to the said lands, with the rights of the Corporation and the plaintiff set out in the orders and with the leasehold interest mentioned in the lease, and made the land subject to the covenants, conditions and contingencies set forth and specified in the caveat. The co-defendants therefore could not acquire the rentals payable under the orders or under the lease without some instrument such as an assignment from the plaintiff. On the facts and the circumstances of the present case and the provisions of the Act, registration of the orders and the caveats by the Corporation constituted notice to all the world

135 [1971] 4 W.W.R. 757.

136 S.B.C. 1965 , c. 33.

137 [1971] 1 W.W.R. 641. See comment by Mirth, (1971) 10 Alta. L. Rev. 126.

${ }^{138}$ Id. at 652-53. 
of all of the terms contained therein, including the right of the plaintiff to receive the rents and payments stipulated in the orders and the lease. To conclude otherwise would defeat the true purpose of the filing of a caveat under an unregistered lease. The plaintiff in the present case therefore had an interest in the leasehold interest filed by way of caveat and can claim protection of it even though he was not the caveator.

Does the decision mean that there must be an application to vary Board orders and a separate assignment of the original surface lessor's interest every time the property is sold in the ordinary way? The answer appears to be yes. Furthermore, it also would appear that Hughes did not even need to take the assignment from Biever in order to retain his interest. An appeal was instituted, but the matter was settled.

\section{The Dalgleish Case}

Two recent Saskatchewan cases have discussed the principles on which compensation for surface rights is to be assessed. In the first of these, Dalgleish v. Worldwide Energy Company Ltd.,139 Rutherford D.C.J. was concerned with the principles of compensation for a well site and access road. On the authority of Re Duthoit and Manitoba (Prov. $)^{140}$ the learned judge accepted that present value was to be determined by reference to the highest and best use to the owner having regard to present and future advantages. ${ }^{141}$ In the present case, such use was as a feed lot and compensation was assessed on that basis. However, he said: ${ }^{142}$

Clearly it is not the fee-simple title which is passing. However, when considering an indefinite period of time which can extend through the best part of a man's working life, and adding damages for injurious affection to remaining lands as has been, or shall be done here, the damages approach a fee-simple taking.

This dictum provides an interesting comparison with that of Feir C.J.D.C. in Twin Oils Ltd. v. Schmidt ${ }^{143}$ pointing out that the court is required to set, not a purchase price, but compensation. It has been specifically challenged in the Notice of Appeal to the Court of Appeal. ${ }^{144}$ Interestingly, the Notice also challenges the judgment of Rutherford D.C.J. on the ground that he "failed to consider evidence establishing all of the advantages which the property possessed to the Appellant both present and future."

Two other procedural matters discussed briefly in the judgment should be mentioned. First, it was said that the "operator" should precede the "owner" at Board hearings although on appeal by the owner, even though it was a hearing de novo, the owner should proceed first. ${ }^{145}$ Secondly, it was said to be "good practice" to have the parties present at any inspection by the Board. ${ }^{146}$

\section{The Vilcu Case}

In Producers Pipelines Ltd. v. Vilcu ${ }^{147}$ the same District Court Judge dealt with compensation for a pipeline easement. The land involved

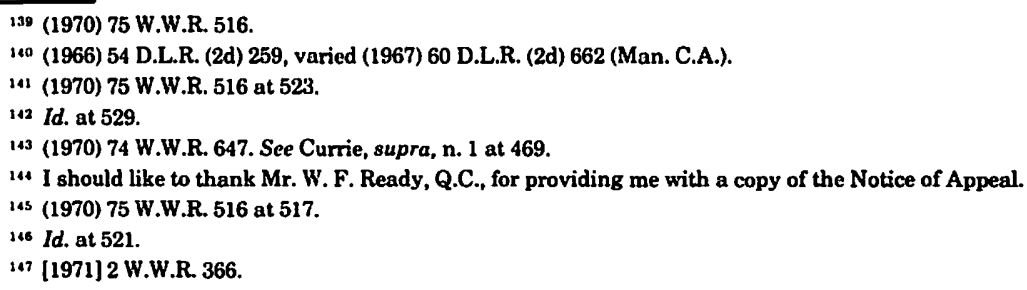


was agricultural, the easement occupying 1.43 acres. Rutherford D.C.J. said: 148

In considering the proper award here, it is necessary to have reference to that portion which may arise: (1) with respect to the right of way; and (2) with respect to the remaining lands.

Under the first heading, it is necessary to determine the value to the owner of the right of way passing by easement to the applicant. A satisfactory and judiciallyrecognized approach to this problem is to determine the value to the owner of the fee simple title as though that passed to the applicant, and then to deduct from that the value to the owner of the net residual rights over the right of way remaining with the owner.

As the 1.43 acres in question were average land in the quarter section valued at $\$ 66$ per acre, the apparent worth was $\$ 94.38$. But it was accepted that the fee simple title for a small portion was worth more per acre than the average for the quarter; considerably more in the view of the owner. Yet, at the same time the residual benefit to the owner was to be considered. Thus, in the result he fixed the compensation to the owner for the right of way at the starting figure of $\$ 94.38$.

In relation to detriment to or injurious affection of the adjoining land, the learned judge said: ${ }^{149}$

[It]t is one thing to have the right to the free, unimpaired use of private property as every owner has in the first instance. It is another thing to have to enforce that right in damages to the remaining land as the owner here is in jeopardy of having to do once the right to easement across the quarter is granted to the applicant. It is a thing of value, if he gives an easement perforce, and thereby assumes the jeopardy, nuisance and inconvenience of the future enforcement of his rights in damages regarding his remaining land, when and if the applicant exercises one or more of his rights under the easement. This is something of value which attaches as a detriment to the adjoining land during the life of the easement reflecting itself to some extent in the market value of the said remaining land. This detriment must relate to the value of the land and to the size of the easement. The basic value of the right of way is worked out on the basis of the same values.

The damage under this head would rarely be expected to exceed the value put on the right-of-way itself and could conceivably fall to zero where, for example, the easement fell along a boundary of the quarter. In the instant case, the easement passed through a central portion of the quarter and compensation was fixed at $\$ 60$.

\section{The Campbell Case}

An interesting comparison with the approach adopted in Saskatchewan in compensating for easements for power lines is provided by Campbell v. Saskatchewan Power Corporation. ${ }^{150}$ In that case it was held by McClelland D.C.J. that the basis of compensation for an easement for the construction and operation of power lines as set out in The Power Corporation Act ${ }^{151}$ was the fair market value of the land together with any damage, less the value of any rights of user remaining. ${ }^{152}$ On the "Blackstock formula", the learned judge commented:153

\footnotetext{
148 Id. at 376-77.

140 Id. at 378.

150 (1970) 71 W.W.R. 182.

isi R.S.S. 1953, c. 35, 8. 26(3).

is2 (1970) 71 W.W.R. 182 at 189.

เsi Id. at 186 .
} 
In so far as the Blackstock formula is based on the principle that small parcels may have a greater value than the whole from which they are taken, it appears to be only common sense. But each case must be considered on its own merits. There may well be instances where the small portion taken is worth less per acre than the whole. It may well be, too, that a narrow strip across a quarter section is worth more per acre than a wide strip. I do not agree that a rigid rule of one and a half times the market value should be followed. In arriving at "the fair market value" of the land included in the various easements, I shall weigh all of the evidence.

Again, a court has declined to follow the formula without unequivocably disapproving it.

\section{H. OIL AND GAS CONTRACTS}

\section{The Leask Case}

In Sial Exploration Ltd. v. Leask, ${ }^{154}$ the Alberta Courts were called upon to again deal with the now familiar problems involved in conditional contracts. On February 11, 1969, the defendants executed a petroleum and natural gas lease of their property in favour of the plaintiff company. The lease provided for a bonus payment of $\$ 6,400$ which, although expressed in the lease to have been paid in cash on the signing thereof, in fact had not been paid. Instead, the Leasks were given a document, generally in the form of a draft for $\$ 6,400$ drawn on the Canadian Imperial Bank of Commerce at Edmonton. In the upper left hand corner were the words "For collection only subject to title approval and 45 days sight." This draft was handed by one of the defendants to his bank on February 14. It was forwarded to Edmonton but the moneys were not sent from the Edmonton branch of the bank until April 7. The 45 day period referred to in the draft had expired on March 28.

Milvain C.J. found that the Leasks had been told at the time of signing the lease that the $\$ 6,400$ would be paid as soon as the plaintiff had cleared title but that, in any event, it would be paid within 45 days, the title problem referred to being a royalty trust agreement previously entered into between the Leasks and the Prudential Trust Company. He held:155

I am satisfied that the true agreement reached on 11th of February was entirely dependent upon the full $\$ 6,400$ being paid, in fact, within 45 days and that unless and until it was paid, there was no enforceable agreement whatever. That being the case, and the payment not having been made within 45 days, the plaintiff has no rights as against the defendant.

This judgment was affirmed by the Appellate Division but the Court added the following alternative ground:156

It is clear that the time for payment was within 45 days from the date on which the lease was signed by the Respondents. This was a fundamental term and, when this payment was not made within that time, the respondents were entitled to treat the lease as being at an end if, in fact, there was any lease at that time.

Thus, it seems that the Court held first that the condition for payment was a condition precedent and that accordingly there was no lease until it was satisfied. If, however, it were a condition subsequent, its breach brought the contract to an end.

\footnotetext{
154 [1971] 4 W.W.R. 654.

iss Id. at 657-58.

156 Id. at 658 .
} 


\section{The Hansink Case}

Another case dealing with the formation of contracts is of interest, although not concerned with oil and gas contracts. In Brixham Investments Ltd. v. Hansink, ${ }^{157}$ the Ontario High Court considered whether a letter of intent constituted a valid contract. The terms of the alleged agreement, which concerned the sale and development of 6.17 acres of land, provided in the first paragraph:

I understand that you and/or your nominees desire to enter into an agreement with me, and/or my nominees, and it is my understanding that the following is our agreement with each other. It is my further understanding that you, and/or your nominees, and I, and/or my nominees, will enter into an agreement to contain, inter alia, the following terms and conditions, not later than the 15th day of March, 1966.

Donnelly J. citing the Calvan case, ${ }^{158}$ stated the problem in these terms:159

The document must be construed to ascertain whether the execution of the further contract was a condition or term of the bargain or whether it was a mere expression of the desire of the parties as to the manner in which the transaction already agreed to would in fact go through. The fact that the contract to be entered into was to contain, inter alia, the terms and conditions as set out in the letter indicates that it was to include other matters.

He then proceeded to hold that, as it was contemplated by the parties that the agreement which would be prepared would include matters not dealt with in the letter, no enforceable agreement was made.160

\section{The Canadian Fina Case}

Another problem of interpretation arose in Canadian Fina Oil Ltd. v. Texas Gulf Sulphur Co. ${ }^{161}$ In this case, the Supreme Court of Canada dealt with the provisions in a gas sales contract dated January 1, 1962, and amended on January 1,1965 , to which the appellant and respondent were parties, governing the method of determination of the price to be paid by the respondent to the appellant and two other companies for acid gas delivered by them to the respondent at the "West Whitecourt plant" near Whitecourt, Alberta. Clause 9(3) of the agreement dealing with price determination provided that certain prices were to be calculated by reference to the price received for sulphur sold from plants in Alberta during the year, "in which sulphur the parties hereto, or any of them, have an interest." The dispute was as to the meaning of the word "interest" in this context, the appellant arguing that "interest" meant proprietary interest while the respondent submitted that the word, as used in the agreement, was intended to have a broad application and would include not only a proprietary, but also a pecuniary interest. ${ }^{162}$

Martland J. found that the word as used in the particular paragraph was not limited to a proprietary interest, but included ^a pecuniary interest. He said:163

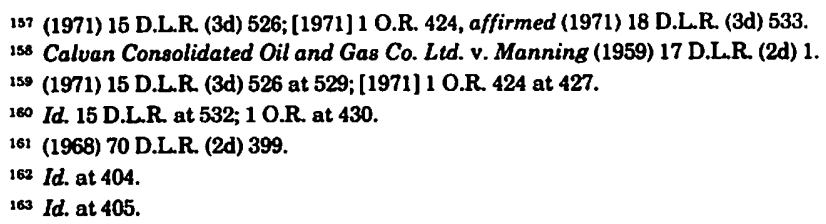

157 (1971) 15 D.L.R. (3d) 526; [1971] 1 O.R. 424, affirmed (1971) 18 D.L.R. (3d) 533.

iss Calvan Consolidated Oil and Gas Co. Ltd. v. Manning (1959) 17 D.L.R. (2d) 1.

ss9 (1971) 15 D.L.R. (3d) 526 at 529; [1971] 1 O.R. 424 at 427.

160 Id. 15 D.L.R. at 532; 1 O.R. at 430.

161 (1968) 70 D.L.R. (2d) 399.

162 Id. at 404.

${ }^{163} \mathrm{Id}$. at 405. 
In my opinion, an interest may, in certain circumstances, consist of a pecuniary interest as distinct from a proprietary interest. The meaning of the word, in any specific agreement, must be ascertained in the context in which it appears.

The significant factor in this particular clause was that it went on to provide "which price can be verified by actual statements from the sellers of such sulphur."164 This obviously indicated that the paragraph was applicable to sales of sulphur made by parties other than the parties to the agreement. ${ }^{165}$

\section{The Wellington and Imperial Case}

While on the subject of gas contracts, it is interesting to note briefly the decision of the Ontario High Court in Re Wellington and Imperial Oil Ltd. ${ }^{166} \mathrm{~A}$ dispute arose as to whether certain payments were royalties under a petroleum and natural gas lease or payments on account of compensation for a gas storage area designated for the same lands as those held under the lease by an order under the Ontario Energy Board Act. ${ }^{167}$ Pennell J. found that the issue was in substance a claim for compensation in respect of a gas right and damages necessarily resulting from the exercise of the authority under the order. ${ }^{168}$ Section 21 of the Act, so far as relevant, provides:

21(1) The Board by order may authorize a person to inject gas into, store gas in and remove gas from a designated gas storage area, and to enter into and upon the land in the area and use the land for such purposes.

(2) Subject to any agreement with respect thereto, the person authorized by an order under subsection 1 ,

(a) shall make to the owners of any gas or oil rights or of any right to store gas in the area fair, just and equitable compensation in respect of such gas or oil rights or such right to store gas; and

(b) shall make to the owner of any land in the area fair, just and equitable compensation for any damage necessarily resulting from the exercise of authority given by such order.

(3) No action or other proceeding lies in respect of such compensation, and, failing agreement, the amount thereof shall be determined by a board of arbitration in the manner prescribed in the regulations, and The Arbitrations Act does not apply.

(4) An appeal lies to the Ontario Municipal Board from an award of the board of arbitration.

In view of these provisions, the learned judge found that the jurisdiction to determine the question had been exclusively conferred on a board of arbitration and that there was no recourse to the court, notwithstanding that the board of arbitration may become involved in a matter of law in interpreting the provisions of the lease and a subsequent unit agreement: ${ }^{169}$

\section{The Alminex Case}

Two cases dealing with unitization have been determined by the courts. The first is Canadian Delhi Oil Ltd. v. Alminex Ltd. ${ }^{170}$ which involved a claim by a party to a unit agreement with a well in the "Buffer Zone" to have the well admitted with a well producibility factor of 1 . It was argued that the factor should be .5 for, with a factor of 1 ,

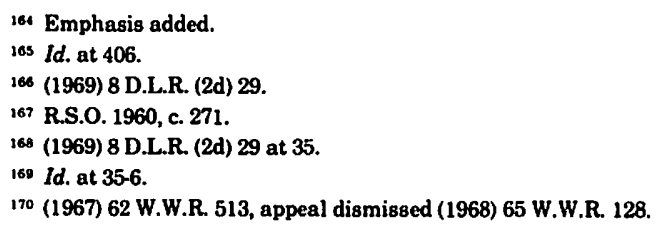


which the appellant claimed to be entitled to, the appellant would receive, as its share in the production of the unit, several hundred thousand dollars more over the lifetime of the unit than the value of the oil which the unit would receive as a result of having the benefit of the tract's allowable. This, it was argued, would lead to a commercial absurdity.

However, Smith C.J.A. delivering the judgment of the court, was not impressed. The issue, he said, was not what a fair share for the appellant of the distributions of the unit would be, but what the appellant was entitled to under the terms of the unitization agreement. ${ }^{171}$ The language in the agreement was in no way ambiguous in its primary meaning which was not controlled by the context and was sensible with reference to the extrinsic circumstances. Therefore, there was no room for the application of the rule in Diederichson v. Farquharson Bros. ${ }^{172}$ that the court should not adopt an interpretation of a document which would result in commercial absurdity but should adopt the primary meaning if unambiguous and sensible with reference to the extrinsic circumstances. ${ }^{173}$ In the case at bar, these circumstances did not deprive the words of all reasonable application according to such primary meaning. ${ }^{174}$

As to damages, Smith C.J.A. said: ${ }^{175}$

The appellant had been refused admission to the unit in accordance with the terms of the agreement. This was a breach of contract entitling the appellant to damages for the loss suffered by the appellant because the agreement was not fulfilled, not to the consideration which the appellant would have received had the agreement to admit been carried out. Therefore I would not interfere with the finding as to the amount which the appellant was entitled to recover.

This was $\$ 60,000$, being $\$ 90,000$ which it was agreed was the amount which would have been paid to the appellant had its well been admitted on the basis fixed by the trial judge less an agreed amount in mitigation of $\$ 30,000$.

One further aspect of the decision remains to be mentioned. The unit agreement provided:176

1304. No Partnership

The duties and obligations of the Parties shall be separate and not joint or collective. Nothing contained in this agreement shall be construed to create a partnership or association.

In relation to this, Smith C.J.A. approved the dictum of Johnson J.A. in Midcon Oil \& Gas Ltd. v. New British Dominion Oil Co. and Brook ${ }^{177}$ that, if in fact an agency is created by the agreement, a denial of that fact in the agreement will not prevent it being $80 .{ }^{178}$

\section{The Gladstone Petroleums Case}

The second case dealing with unitization is Gladstone Petroleums Ltd. v. Husky Oil (Alberta) Ltd. ${ }^{179}$ This was an application for an in-

\footnotetext{
i7 Id. at 518, Johnson and KaneJJ.A., concurring.

172 [1898] 1 Q.B. 150 at 159.

173 (1967) 62 W.W.R. 513 at 520.

174 Id. at 521 .

173 Id. at 530-31.

176 The clause is in identical terms to clause 1304 of the Model Oil and Gas Unit Agreement of the 28th Mines Ministers Conference, 1971.

177 (1957) 21 W.W.R. 228 at 236, affirmed [1958] S.C.R. 314

178 (1967) 62 W.W.R. 513 at 531.

179 (1969) 9 D.L.R. (3d) 415. See also (1968) 66 W.W.R. 641
} 
terim injunction restraining the defendant from converting an oil well into a water injection well and from drilling any further water injection wells on the tracts in a unit agreement. The plaintiff had commenced proceedings for the recovery of its tracts.

Johnson J. of the Saskatchewan Queen's Bench, held that an injunction should issue in view of the fact that if the plaintiff succeeded at trial, it would be entitled to have its tracts returned to it as far as possible in the same condition as when they were unitized, whereas it was agreed that if the water injection programme on the plaintiff's tracts were continued, the wells on its property would be worthless as oil producers. ${ }^{180}$

\title{
I. SURFACE RECLAMATION
}

\section{The Fox Coulee Case}

The first decision under the Alberta Surface Reclamation Act ${ }^{181}$ was reported recently. In Buchta v. Fox Coulee Coals Ltd. and The Surface Reclamation Council, ${ }^{182}$ Rowbotham D.C.J. heard three appeals, in the form of a trial de novo, respecting reclamation certificates issued by The Surface Reclamation Council. Both the Council and the Act itself were criticised. The learned judge said:183

\begin{abstract}
After hearing the evidence, after viewing the surface of the lands and inspecting them thoroughly by walking over them, and after viewing adjacent and comparable lands in the area, it is my opinion that the condition of the surface of the lands in question is totally unsatisfactory. None of the top soil was saved. The overburden was simply pushed over the hillsides into the valleys and streams below. The bare hardpan clay was left exposed for erosion after the coal had been removed. Runoff water laden with silt and coal dust was allowed to foul the streams. Much of the surface was covered with a heavy growth of Russian thistle and other noxious weeds which were allowed to blow and spread to adjoining lands. A token attempt to sow grass by broadcasting seed failed to produce any grass cover. Briefly, the lands were left in a mess.

I cannot understand the basis upon which the Council issued reclamation certificates. Either it was incompetent, careless or indifferent to its duties concerning the administration of the Act or it was more concerned with assisting the operator than with the proper administration of the Act.
\end{abstract}

The Council, he found, should have issued an order directing the performance of such acts as were necessary to reclaim the land in question. He then proceeded to a detailed list of work ordered to be done within one year from judgment. ${ }^{184}$

So far as the Act was concerned, the learned judge suggested that it should be amended to provide for the depositing of a bond by the operator "in a sum of money sufficient to ensure the reclamation of the surface of land expropriated for strip mining purposes." 185

\section{J. THE NATIONAL OIL POLICY}

Although not involving oil and gas law as such, it may be interesting to conclude the survey of recent cases with a discussion of the con-

\footnotetext{
iso Id. at 419-20.

181 R.S.A. 1970, c. 356.

182 [1971] 2 W.W.R. 476.

183 Id. at 477 .

184 Id. at 478

iss Id.
} 
stitutional challenge made during the past year to the national oil policy.

\title{
1. The Caloil (No. 1) Case
}

Caloil Inc. applied to the National Energy Board for a licence to market imported gasoline west of the Ottawa Valley. Two other licences were issued to Caloil subject to conditions. In Caloil Inc. v. AttorneyGeneral of Canada (No. 1), 186 the plaintiff sought a declaration that that Part VI of The National Energy Board Act ${ }^{187}$ and the regulations thereunder ${ }^{188}$ which purported to authorize the granting of such conditional licences were unconstitutional.

The action was a direct challenge to the validity of the national oil policy that there is to be no marketing of imported oil west of the Ottawa Valley. In refusing the application of Caloil for a licence to market in Ontario, west of the Ottawa Valley, the National Energy Board had stated the policy in these terms: ${ }^{189}$

\begin{abstract}
The Board considers it appropriate and desirable for it to accompany this decision with a statement of the policy it follows in regard to the issuance of licences to import gasoline.

It is prepared at this time to issue licences to import gasoline into Region I (the Atlantic Provinces) and Region II (Quebec and a part of Eastern Ontario-demarcation on attached map). The one restriction which the Board will apply to such licences is that no gasoline will be transferred by the importer or any person to whom the importer may sell, into Ontario west of the Ottawa Valley line, except with the consent of the Board. The Board has, therefore, conditoned accordingly all import licences it has issued and intends, in the absence of special circumstances in an individual case, to continue this practice until such time as it has developed a better method of assuring the discharge of its responsibilities respecting supplies of gasoline in Ontario west of the Ottawa Valley line.

The Board understands its responsibility regarding the movement of imported gasoline into Ontario west of the Ottawa Valley line, whether the movements are direct or by subsequent transfer, to be to limit the volumes to those which are necessary to ensure adequate supplies, to minimize any price increases to consumers and to meet special hardship circumstances of companies whose legitimate interests might be adversely affected by the policy. In approaching such matters, the Board will give full consideration to the fact that the Ontario refiners as a matter of policy have been called upon to supply Ontario west of the Ottawa Valley line with petroleum products refined from Canadian crude. It is recognized that the Ontario refiners cannot fully meet the competition of seasonal imports of gasoline, especially those associated with spot purchases of gasoline and tanker services in international markets. In its consideration of any applications by importers for the Board's consent to transfer gasoline into Ontario west of the Ottawa Valley line the Board, however, will carefully assess any evidence relating to the availability of supply from the Ontario refiners.
\end{abstract}

The legislative scheme which it was claimed authorized this policy rested on Sections 81, 82, 85 and 87 of The National Energy Board Act. Under Section 81, no person may import any gas except under the authority of and in accordance with a licence issued under Part VI thereof. Section 82 authorizes the Board to issue licences upon such terms and conditions as are empowered by the regulations, including specifically restrictions "as to area, quantity or time or as to class or kind of products." Under Section 85, the Governor in Council was empowered to make regulations for the purposes of that Part, again

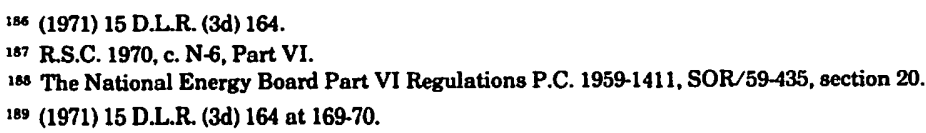


specifically including the quantities that may be imported under licences and "any other terms or conditions to which licences may be subject." Section 87 authorized the extension of the Part to oil by proclamation, such a proclamation being issued on May 7, 1970.

On May 5, 1970, the Regulations under Part VI were amended to include Section 20, which reads in part: 190

20(1) Subject to subsection (2), no person may export or import oil or oil products otherwise than under the authority of and in accordance with a licence issued by the Board.

(4) The Board may issue licences to import motor gasoline through Customs ports in Regions I and II and the Board may make any or all of such licences subject to the condition that the importer shall not, without the consent of the Board,

(a) transport or cause to be transported any motor gasoline from Regions I or II to Region III, or

(b) sell or deliver to any third party any motor gasoline except on the condition that such sale or delivery is made for consumption within Regions I or II, but the consent of the Board shall not in any case be required under paragraph (b) in respect of any quantity of motor gasoline sold or to be sold by the importer in Regions I or II to retailers engaged solely in the business of retailing within Regions I or II or directly to consumers purchasing in Regions I or II.

(5) The Board may incorporate in any licence issued under this section such terms as it deems necessary to secure compliance with these Regulations.

The section did not apply to the importing of oil other than gasoline and to certain Regions as defined in the Regulations.

Jackett $P$. found first that, in considering Part VI and the Regulations, it was important to have in mind that there was no prohibition as such of the movement of gasoline across provincial borders. Part VI was clearly a law in relation to the regulations of international trade and must stand or fall as such in view of the way in which it was framed. ${ }^{191} \mathrm{He}$ continued: ${ }^{192}$

I reach the conclusion then that, on the authorities to which my attention has been drawn, once goods are imported into Canada, they ordinarily fall, from the point of view of trade regulations, into the same category as goods produced in Canada, and fall to be regulated, from the trade point of view, by Parliament or the Legislatures depending on whether they find their way into paths leading to destinations in or outside the Province where they are situate.

[O]n the authorities to which I have referred, when goods are brought into Canada to supply a part of the consumption requirements of the country, once imported they merge with the other goods in the country and do not maintain a separate identity from the point of view of jurisdiction to regulate trade inside Canada. Imported goods are no different as far as that jurisdiction is concerned, from other goods, once they are imported.

In my view, therefore, it is not a proper part of the sort of international trade regulation law that Part VI typifies to confer on a board power to govern the movements within a particular Province of imported goods after they have been imported.

In any event, there was another ground on which Section 20 of the Regulations could not be supported even if it were a proper part of such a scheme for Parliament to regulate the movement of imported goods as such. Section 20 did not purport to confer authority on the Board to regulate the movement of imported gasoline but authorized the imposi-

190 P.C. 1970-775, SOR/70-193, 8. 3; later rep. \& sub. P.C. 1970-1419, SOR/70-372, section 11 (August 12, 1970).

191 (1971) 15 D.L.R. (3d) 164 at 171.

192 Id. at 173-74. 
tion of a prohibition on a licensee, as a condition of getting a licence, against transporting any motor gasoline from east of the Ottawa Valley. Jackett P. rightly pointed out that the words "any motor gasoline" applied to all gasoline in the hands of the licensee even if produced in Canada. This certainly was not a law which purported to regulate imported goods. ${ }^{193}$ Thus, the scheme in Part VI of the Act and Section 20 of the Regulations was beyond the power of Parliament insofar as it authorized the prohibition of the importation of motor gasoline except subject to the conditions set out in Section 20(4).

\section{The Caloil (No. 2) Case}

Following this decision, Section 20 of the Regulations was promptly amended. The Board, having the power under the Act to amend the Regulations, "did not consider itself irreparably defeated and, although one amendment was invalid, another, of different scope, might meet a better fate. No sooner said than done."194 The new Section 20 provides: 195

20(1) In this section and section 21 consumption means the placing of oil in tanks connecting to an internal combustion engine for purposes of operating such engine.

(2) Where the Board is of the opinion that importation of oil that is the subject of an application for a licence to import into Canada will be consistent with the development and utilization of Canadian indigenous oil resources, it may issue a licence to import oil for consumption in the area of Canada specified therein, in such quantities, at such times and at such points of entry into Canada as it may consider appropriate.

(3) Any licence issued by the Board pursuant to subsection (2) may be issued on the condition that the oil to be imported will be consumed in the area of Canada specified in the licence.

(4) Where the Board is not reasonably satisfied that the consumption of oil to be imported will be in the area of Canada specified in the application for a licence and that the terms of the licence to be issued will be complied with, it shall not issue a licence.

This led to Caloil Inc. v. Attorney-General of Canada (No. 2), "the second act, or if you prefer another metaphor, to the second lap of this jurisdictional steeplechase." 196

Dumoulin J. saw his task, not in comparing the new Regulations with the old, but in considering whether, apart from any earlier Regulations, it was constitutional. ${ }^{197}$ On the authority of Re Fisheries Act, 1914; A.-G. Can. v. A.-G. B.C. ${ }^{198}$ he proceeded from the assumption, first, that Parliament alone has legislative competence over trade and commerce both where importation and exportation are concerned. Secondly, this power extended to interprovincial trade. ${ }^{199}$ Applying these principles to the present case, he found:200

Section 20, before amendment, indiscriminately included "any motor gasoline in the hands of the licensee even if it is produced in Canada" (ex. R-2, ante, p. 174), an extensive clause which, going beyond the boundaries of interprovincial trade, trenched on the free exercise of civil rights in the Provinces. Was this shortcoming

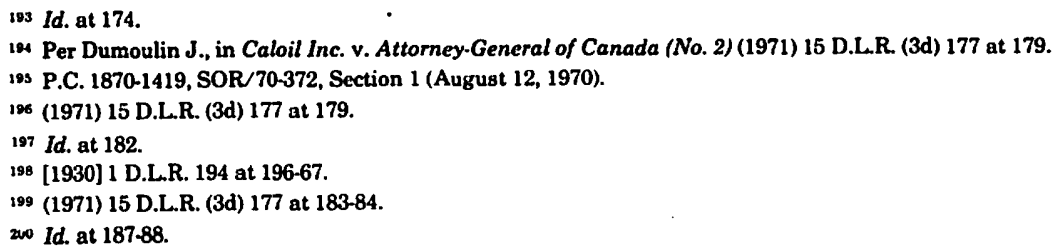


not rectified in the recent text which provides instructions on the quantities imported, the time of importations, the region of Canada where such oil would be consumed?

It goes without saying that everyone is in agreement on the commercial nature of such major transactions and recognizes the right vested in the federal authority to prohibit any product, when necessary, from entering the country. As the venerable philosophical adage observes, "He who can do more can do less." In the present case, for purposes that the Board had to provide for, the regulations of this vital trade must be exercised where it takes place, namely, in all points of the 10 Provinces and of the two Territories of Canada. Then, the amendment decreed by the Order in Council of August 12,1970, empowers the Board to specify in what quantities, at what times and to which regions gasoline can be imported, from its place of origin to its area of consumption; it brands it to some extent and prevents its confusion with oil extracted in Canada. It may be that this is a suitable distinction; however, it appears sufficient to me. (sic)

Accordingly, he held the new Regulations, Section 20 in particular, to be intra vires.

An appeal by Caloil to the Supreme Court of Canada was dismissed. ${ }^{201}$

\section{K. LEGISLATIVE DEVELOPMENTS}

The 1971 Session of the Alberta Legislature was notable for a collection of legislation dealing specifically with the environment. It is proposed to consider briefly some of the more important provisions which relate directly to oil and gas production within the Province.

\section{The Energy Resources Conservation Act}

The most sweeping statutory changes relating to oil and gas production have been effected by The Energy Resources Conservation Act.202 Under this Act, the Oil and Gas Conservation Board has been reconstituted as the "Energy Resources Conservation Board" 203 with enlarged powers and duties. Broadly speaking the powers of the Board are extended to deal with "energy resources" generally, these being defined as "any natural resource within Alberta that can be used as a source of any form of energy."204

The purposes of the Act are:205

(a) to provide for the appraisal of the reserves and productive capacity of energy resources and energy in Alberta,

(b) to provide for the appraisal of the requirements for energy resources and energy in Alberta and of markets outside Alberta for Alberta energy resources or energy, (c) to effect the conservation of, and to prevent the waste of, the energy resources of Alberta,

(d) to control pollution and ensure environment conservation in the exploration for, processing, development and transportation of energy resources and energy,

(e) to secure the observance of safe and efficient practices in the exploration for, processing, development and transportation of the energy resources of Alberta,

$(f)$ to provide for the recording and timely and useful dissemination of information regarding the energy resources of Alberta, and

(g) to provide agencies from which the Lieutenant Governor in Council may receive

information, advice and recommendations regarding energy resources and energy.

The power to implement these purposes is found in Section 23 which provides that the Board, with the approval of the Lieutenant Governor

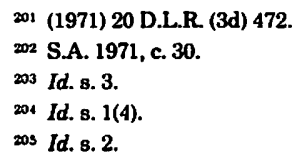


in Council, may take such action and make such orders and give directions as it considers necessary to effect the purposes of the Act and "as are not otherwise specifically authorized by this Act," a provision with potentially far-reaching consequences. In addition, under Section 24 , the Board is specifically charged with the responsibility of making enquiries and investigations, preparing studies and reports on any matter within the purview of any Act administered by it and relating to energy resources and energy. It may also recommend to the Lieutenant Governor in Council such measures as it considers necessary or advisable in the public interest related to the exploration for, production, development, conservation, control, transportation, transmission, use and marketing of energy resources and energy.

It will be noted that the powers under Section 24 are largely advisory but those under Section 23 are to make orders and directions with the approval of the Lieutenant Governor in Council. It seems that the general intention of the scheme is that specific matters will be delegated to the Board under other Acts. In the meantime, it is suggested that the impact of the legislation will depend to a large extent on the view which the Board takes of its own function under Section 23.

Some specific responsibilities are delegated to the Board under the consequential amendments. For example, under The Pipe Line Act, ${ }^{206}$ responsibilities formerly with the Minister of Mines and Minerals have been transferred to the Board. ${ }^{207}$ In particular, it is the Board and not the Minister, which now issues permits for pipelines. The Oil and Gas Conservation Act ${ }^{208}$ also has been amended, first to delete those provisions establishing the Board as these are now found in the new Act, and also adding a significant new section dealing with oil pollution. ${ }^{209}$ This provides that where oil escapes and it appears to the Board that such oil may not otherwise be contained and cleaned up forthwith, the Board may direct the pipeline operator or licensee to take steps it considers necessary, or enter the area and conduct such operations as it considers necessary to contain and clean up oil which has spilled and to prevent further escape of oil. The Board may dispose of spilled oil and direct by whom and to what extent any deficit arising from clean up operations is to be paid.

However, the petroleum industry is not expected to finance the enlarged responsibilities of the Board under the new Act. Under Section 18, all expenses incurred by the Board in the performance of its duties under The Oil and Gas Conservation Act, and other Acts for which the Board was already responsible, are to be paid from moneys provided in accordance with that Act, but otherwise are to be paid from the General Revenue Fund.

Finally, the Act establishes the "Energy Committee" consisting of the President of the Executive Council, the Deputy Ministers of the Environment, Industry and Tourism, Lands and Forests and Mines and Minerals, the Chairman of the Energy Resources Conservation Board, the Chairman of the Public Utilities Board and one other member. ${ }^{210}$ The function of the Committee is to bring about a continuous liaison

\footnotetext{
206 R.S.A. 1970, c. 275.

207 S.A. 1971 , c. 30, s. $51(1)(b)$.

200 R.S.A. 1970, c. 267.

209 S.A. 1971, c. 30, 8. 50(7)(f), adding a new section 133.1 .

210 Id. 8. 19.
} 
between all departments and agencies concerned with the administration of Alberta's energy resources and advise the Lieutenant Governor in Council on policy matters concerned with the administration of energy resources and affecting more than one government department or agency. ${ }^{211}$

\section{The Department of the Environment Act}

Complementing this Act is The Department of the Environment Act 212 dealing with natural resources which are defined to mean "Land, plant life, animal life, water and air."213 For the purposes of the Act, matters pertaining to the environment are:214
(a) the conservation, management and utilization of natural resources;
(b) the prevention and control of pollution of natural resources;
(c) the prevention of noise and the control of noise levels resulting from commercial
or industrial operations in so far as they affect the environment in the vicinity of those operations;
(d) economic factors that directly or indirectly affect the ability of persons to carry out measures that relate to the matters referred to in clauses (a), (b) and (c);
(e) any operations or activities
(i) that adversely affect or are likely to adversely affect the quality or quantity of any natural resource, or
(ii) that destroy, disturb, pollute or alter or make use of a natural resource or are likely to do so;
(f) the preservation of natural resources for their aesthetic value;
(g) laws in force in Alberta that relate to or directly or indirectly affect the ecology
of the environment or natural resources.

Section 3 creates the Department of the Environment presided over by the Minister of the Environment. Under Section 10, the Natural Resources Co-ordinating Council is established, consisting of the Deputy Ministers of the Environment, Agriculture, Health and Social Development, Highways and Transport, Industry and Tourism, Lands and Forests, Mines and Minerals and Municipal Affairs and the Chairman of the Energy Resources Conservation Board. The function of the Council is to inquire into matters pertaining to the environment and to review policies, with reports and recommendations to the Minister. A further committee, the Conservation and Utilization Committee, is constituted under Section 11, consisting of representatives of various government departments. Its function is to enquire into any matter pertaining to the environment at the direction of the Co-ordinating Council.

After struggling through the administrative provisions and sorting out the various committees created, one finds in the Act significant powers to protect the environment. Again, their effectiveness, however, will depend on the views taken by the various bodies of their own functions.

Under Section 13, the Minister may formulate plans for "effective co-ordinated action in cases of emergency to prevent, alleviate, control or stop the destruction or loss of, or damage to, a natural resource or to human beings as a result of the pollution of a natural resource." Then, upon the report of the Minister, the Lieutenant Governor in Council may declare a state of emergency pursuant to which he may

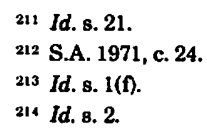


require government employees, any municipal corporation "or any other corporation or organization" or any other person not exempted by the regulations to provide his or its services to prevent or control the damage or pollution referred to in the order. ${ }^{215}$ It should be noted that is is only persons, not corporations to which the exemption by regulations provision applies.

The next significant provision is Section 15 which empowers the Lieutenant Governor in Council to establish by regulation Restricted Development Areas where the Minister reports that this is necessary for the purpose of preventing pollution, protecting a watershed, retaining the environment of the Area in a natural state or preventing the deterioration of the quality of the environment of the Area "by reason of the development or use of land in the Area incompatible with the preservation of that environment." In such Areas, he may by regulation provide for: 216

(a) the control, restriction or prohibition of any kind of use, development or occupation of land in the Area prescribed in the regulations;

(b) the control, restriction or prohibition of the exercise of any power specified in the regulations by any specified Minister of the Crown, government official or government agency;

(c) the removal of any buildings, improvements, materials or animals from the Area, and the payment of compensation by the Crown for any loss resulting therefrom;

(d) the control, restriction or prohibition of the dumping, deposit or emission within the Area of any substance specified in the regulations;

(e) the authorizing of the acquisition by purchase or expropriation by the Minister of any estate or interest in land in the Area;

Perhaps the most threatening provision from industry's point of view is the power vested in the Minister under Section 16 to issue "stop orders" where he is satisfied that any person has contravened the Act or regulations or any other Act or regulation the contravention of which, in the opinion of the Minister, is causing or is likely to cause the destruction, damage or pollution of a natural resource. This amounts to a right to issue an injunction for breach of a statute without recourse to the Courts, although it is interesting to note that the Minister may apply to the Supreme Court of Alberta for a court order directing the person to comply with the stop order, breach of which is to be dealt with as a civil contempt. Failure to comply with the Minister's order is in any event accompanied by a maximum fine of $\$ 10,000$ per day. There is, however, an appeal within 15 days of a stop order to the Minister in which case he is obliged to refer the matter to the Environment Conservation Authority217 for a hearing but he is not obliged to accept its recommendations.

Again, the provisions of this Act should be examined carefully, particularly the wide regulation-making power in Section 17. The Act came into force on April 1, 1971.

\section{Other Legislation}

Several other Acts dealing with protection of the environment should be examined. They include The Clean Air Act, ${ }^{218}$ The Clean Water

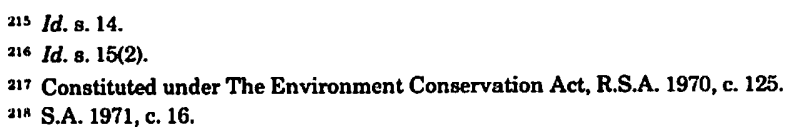


Act, ${ }^{219}$ The Wilderness Areas Act, ${ }^{220}$ and The Forest and Prairie Protection Act. ${ }^{221}$ Consequential amendments to The Electric Power and Pipe Line Assessment Act ${ }^{222}$ and The Municipal Taxation Act ${ }^{223}$ providing tax exemptions for lands and improvements used for the treatment or disposal of waste materials to control or abate pollution should also be considered. 